\title{
Analysis of Ground-Water Flow Along a Regional Flow Path of the Midwestern Basins and Arches Aquifer System in Ohio
}

By ROBERT H. HANOVER

U. S. GEOLOGICAL SURVEY

Water-Resources Investigations Report 94-4105

REGIONAL AQUIFER-SYSTEM ANALYSIS PROGRAM

Columbus, Ohio

1994 


\title{
U.S. DEPARTMENT OF THE INTERIOR
}

\author{
BRUCE BABBITT, Secretary
}

U.S. GEOLOGICAL SURVEY

GORDON P. EATON, Director

For additional information write to:

Copies of this report can be purchased from:

Project Chief, MBA-RASA

Water Resources Division

U.S. Geological Survey

975 W. Third Avenue

Columbus, Ohio 43212
U.S. Geological Survey

Earth Science Information Center

Open-File Reports Section

Box 25286, MS 517

Denver Federal Center

Denver, Colorado 80225 


\section{CONTENTS}

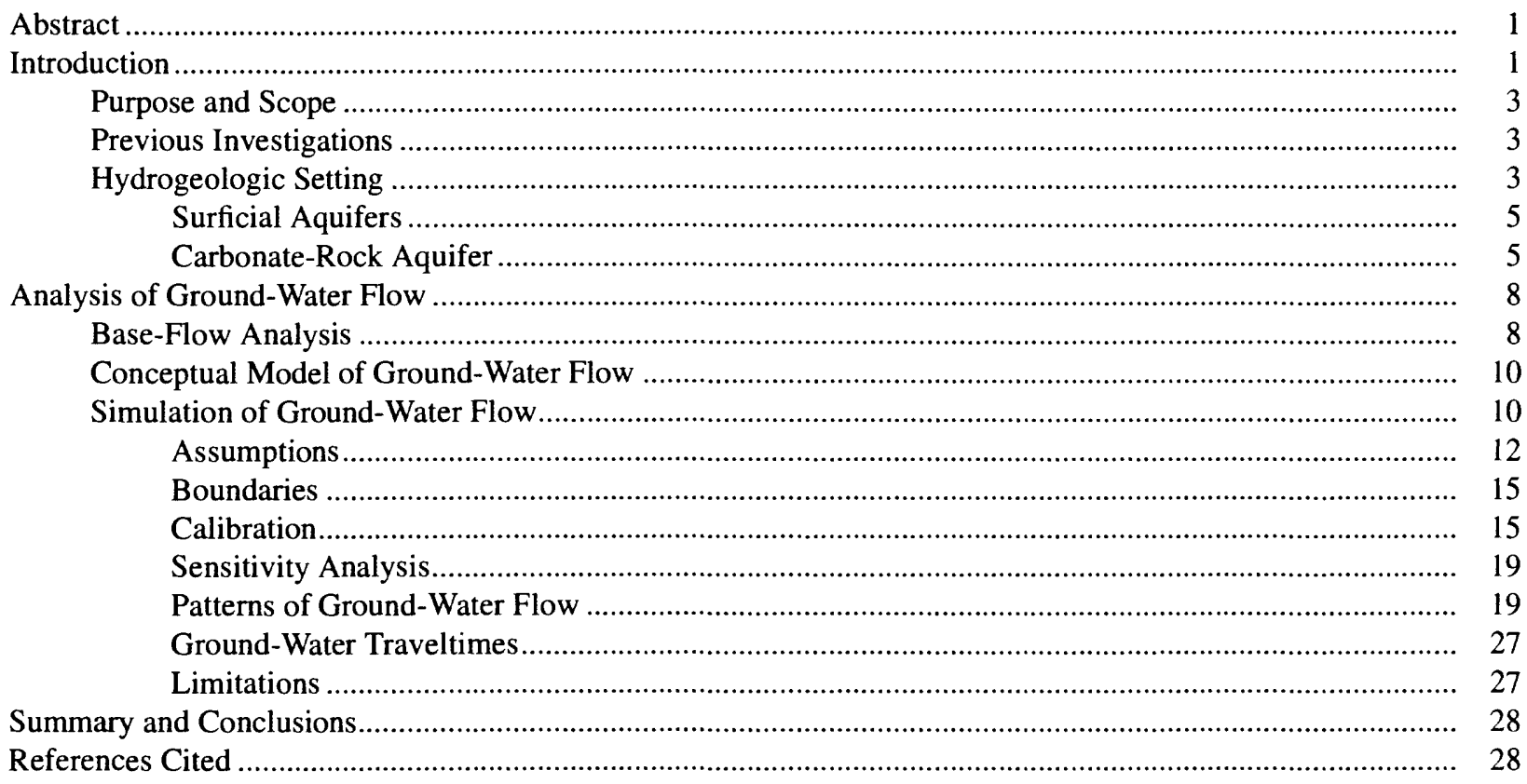

\section{FIGURES}

1-4. Maps showing:

1. Location of the Midwestern Basins and Arches Regional Aquifer-System study area and major structural basins and arches

2. Generalized bedrock geology of Ohio, location of streamflow-gaging stations used in hydrograph separation, and the regional flow path

3. Potentiometric surface of the carbonate-rock aquifer in central-western and northwestern Ohio and the regional flow path.

4. Generalized glacial deposits of Ohio and the regional flow path.

5. Chart showing relation between geologic and hydrogeologic units in central-western and northwestern Ohio

6. Graphs showing base-flow-duration curves for the Scioto River Basin near Prospect, Ohio, and the Blanchard River Basin near Findlay, Ohio

7. Conceptual hydrologic section showing generalized altitude of land surface, water-table surface, bedrock surface, and directions of ground-water flow along the regional flow path...

8. Schematic section showing horizontal and vertical model discretization and location of the Scioto and Blanchard Rivers and Sandusky Bay, Ohio, along the regional flow path ...

9. Linear regression plot of water-table altitudes on land-surface altitudes for 50 wells completed in the glacial deposits in the Ohio counties through which the regional flow path passes ..........................

10-14. Graphs showing:

10. Comparison of simulated hydraulic head to measured hydraulic head for layer 2 in the model of the regional flow path, central-western and northwestern Ohio ......

11. Sensitivity of simulated hydraulic heads to change in transmissivity of layer 2 , leakance, recharge, and general-head-boundary conductance in the model of the regional flow path, centralwestern and northwestern Ohio..... 


\section{FIGURES-Continued}

12. Sensitivity of simulated ground-water discharge to the Scioto and Blanchard Rivers to changes in hydraulic conductivities of layer 1 and transmissivities of layer 2 in the model of the regional flow path, central-western and northwestern Ohio

13. Sensitivity of simulated ground-water discharge to the Scioto and Blanchard Rivers in response to changes in values of leakance and recharge in the model of the regional flow path, centralwestern and northwestern Ohio

14. Sensitivity of simulated ground-water discharge to the Scioto and Blanchard Rivers in response to changes in values of riverbed conductivity and general-head-boundary conductance in the model of the regional flow path, central-western and northwestern Ohio

15. Schematic section showing selected ground-water pathlines and traveltimes for ground-water particles and carbon ${ }^{14}$ ages for ground-water samples from wells completed in the carbonaterock aquifer (layer 2 ) along the regional flow path, Ohio

\section{TABLES}

1. Average annual recharge to the ground-water flow system within the Scioto and Blanchard River Basins, Ohio, as estimated from hydrograph separation.

2. Sustained ground-water discharge per foot of river reach to the Scioto and Blanchard Rivers, Ohio, as estimated from analysis of base-flow-duration curves

3. Selected hydraulic heads and ground-water discharges from sensitivity analysis of hydrologic parameters used in calibrating the model of the regional ground-water flow path, Ohio 


\begin{tabular}{rll}
\hline Multiply & By & \multicolumn{1}{c}{ To obtain } \\
\hline inch (in.) & 25.4 & \\
foot $(\mathrm{ft})$ & 0.3048 & millimeter \\
mile $(\mathrm{mi})$ & 1.609 & meter \\
square foot $\left(\mathrm{ft}^{2}\right)$ & 0.09290 & kilometer \\
square mile $\left(\mathrm{mi}^{2}\right)$ & 2.590 & square meter \\
inch per year $(\mathrm{in} / \mathrm{yr})$ & 25.4 & square kilometer \\
foot per mile $(\mathrm{ft} / \mathrm{mi})$ & 0.1894 & millimeter per year \\
foot per minute $(\mathrm{ft} / \mathrm{min})$ & 0.3048 & meter per kilometer \\
foot per day $(\mathrm{ft} / \mathrm{d})$ & 0.3048 & meter per minute \\
cubic foot $\left(\mathrm{ft}^{3}\right)$ & 0.09290 & meter per day \\
foot squared per day $\left(\mathrm{ft}^{2} / \mathrm{l}\right.$ & 0.02832 & meter squared per day \\
cubic foot per second $\left(\mathrm{ft}^{3} / \mathrm{s}\right)$ & 0.02832 & cubic meter \\
cubic foot per day $\left(\mathrm{ft}^{3} / \mathrm{d}\right)$ & 0.02832 & cubic meter per second \\
gallon per minute $(\mathrm{gal} / \mathrm{min})$ & 0.06309 & cubic meter per day \\
million gallons per day $(\mathrm{Mgal} / \mathrm{d})$ & 0.04381 & liter per second
\end{tabular}

\footnotetext{
${ }^{1}$ This is the unit used to express transmissivity, a measure of the capacity of an aquifer to transmit water. Conceptually, transmissivity is cubic foot (of water) per day per square foot (of aquifer area) times foot of aquifer thickness. In this respect, the unit is reduced to its simplest terms.
}

Sea level: In this report, "sea level" refers to the National Geodetic Vertical Datum of 1929a geodetic datum derived from a general adjustment of the first-order level nets of both the United States and Canada, formerly called Sea Level Datum of 1929. 


\title{
Analysis of Ground-Water Flow Along a Regional Flow Path of the Midwestern Basins and Arches Aquifer System in Ohio
}

\author{
By Robert H. Hanover
}

\section{Abstract}

A cross-sectional analysis of ground-water flow in central-western and northwestern Ohio was done as part of the Midwestern Basins and Arches Regional Aquifer-System Analysis project. The Midwestern Basins and Arches aquifer system is a regional ground-water system composed of carbonate bedrock of Silurian and Devonian age and overlying glacial deposits of Quaternary age. Results from a steady-state, finite-difference crosssectional model and from base-flow analysis of two major rivers in the study area were used to describe patterns of ground-water flow, to evaluate stream-aquifer interaction, and to quantify recharge and discharge within the ground-water flow system along a selected regional ground-water flow path. The selected regional flow path begins at a regional topographic high in Logan County, Ohio, and ends in Sandusky Bay (Lake Erie), a regional topographic low.

Recharge to the ground-water system along the selected regional flow path was estimated from hydrograph separation of streamflow and averaged 3.24 inches per year. Computer simulations of ground-water flow indicated that 84 percent of the water entering the ground-water system along the regional flow path flows less than 5 miles from point of recharge to point of discharge and no deeper than the surficial aquifers. The distance and depth that ground water travels along the regional flow path and the traveltime from point of recharge to point of discharge are controlled largely by where ground water enters the flow system. Ground water entering the flow system in the vicinity of major surface-water divides generally travels farther, deeper, and longer than ground water entering the flow system elsewhere along the regional flow path. Factors affecting patterns of ground-water flow along the regional flow path are (1) the water-table configuration, (2) the depth-to-lateral-extent ratio of the aquifer system, (3) stratigraphy, and (4) subsurface variations in permeability. Particle-tracking simulations substantiate the concept that the 80-mile-long regional flow path is within a continuous ground-water basin. Estimated traveltimes for ground water from the regional high to Sandusky Bay range from 22,000 to 40,700 years, given a range of porosities from 8 to 22 percent for the carbonate-rock aquifer.

\section{INTRODUCTION}

The Regional Aquifer-System Analysis (RASA) Program of the U.S. Geological Survey (USGS) was initiated by Congress in 1978 to study many of the major aquifer systems in the United States (Sun, 1984). The objective of the program is to study the geology, hydrology, and geochemistry of major aquifer systems from a regional perspective.

The Midwestern Basins and Arches aquifer system was selected for study because it is a major source of ground water for industrial, agricultural, and domestic use for more than 7 million people. Ground-water pumpage from this aquifer system exceeded $433 \mathrm{Mgal} / \mathrm{d}$ in 1990 (Beary, 1993). The study area for the Midwestern Basins and Arches RASA project encompasses approximately the eastern half of Indiana and the western half of Ohio (about 44,000 $\mathrm{mi}^{2}$ ) (fig.1). 


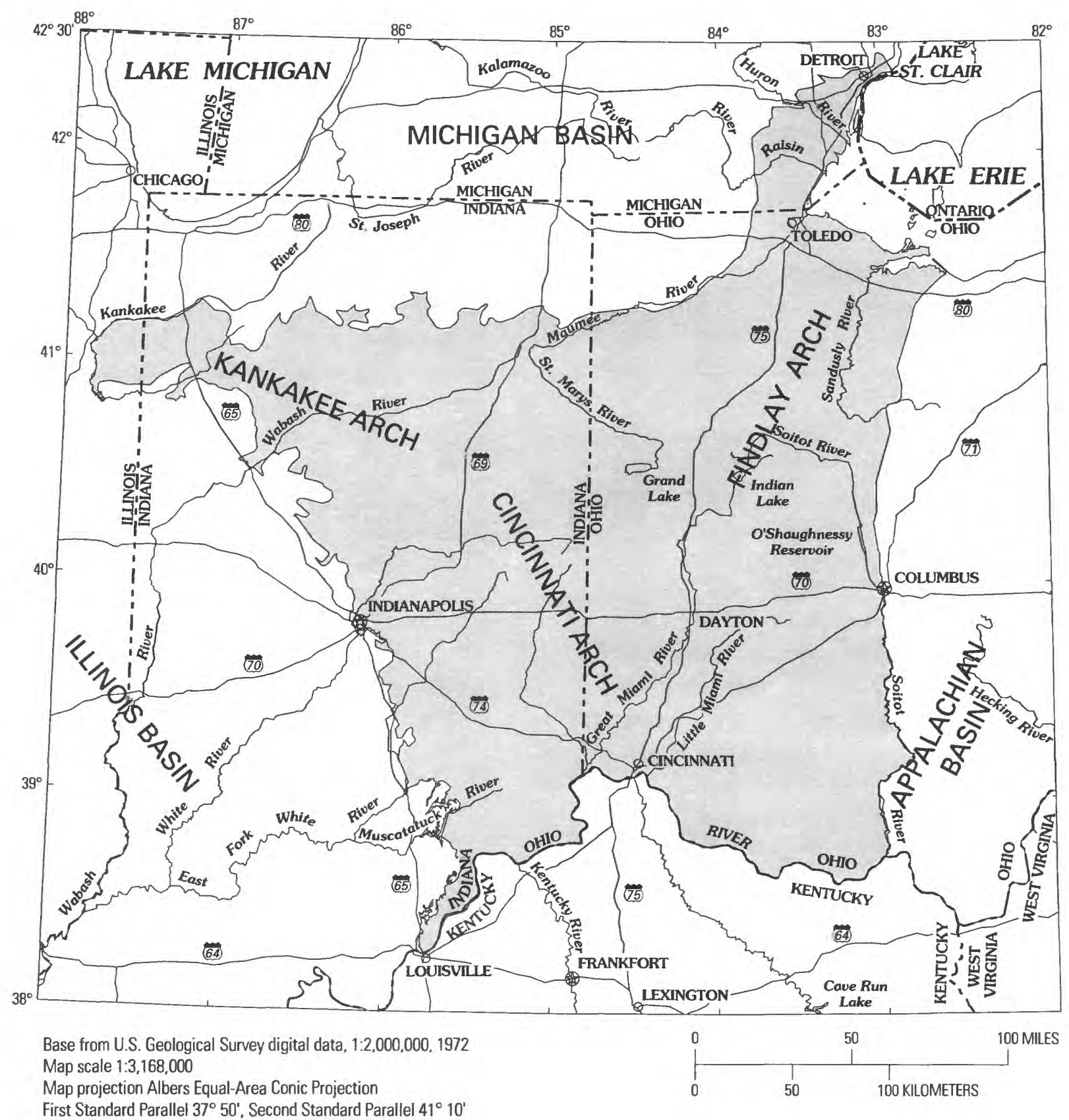

First Standard Parallel $37^{\circ} 50^{\circ}$, Second Standard Parallel $41^{\circ} 10^{\prime}$

Central Meridian $84^{\circ}$

EXPLANATION

Midwestern Basins and Arches Regional Aquifer-System

Analysis study area

Figure 1. Location of the Midwestern Basins and Arches Regional Aquifer-System Analysis study area and major structural basins and arches. 
The regional aquifer system is composed of carbonate bedrock of Silurian and Devonian age and overlying glacial deposits of Quaternary age. The hydrologic boundaries of the regional aquifer system are generally coincident with the subcrop boundaries of the freshwater part of the carbonaterock aquifer.

A cross-sectional analysis of flow along a selected regional ground-water flow path (hereafter referred to as the "regional flow path") in centralwestern and northwestern Ohio (fig. 2) was done to determine patterns of ground-water flow and to quantify stream-aquifer relations within this part of the Midwestern Basins and Arches Region. A conceptual model of ground-water flow along the regional flow path was evaluated by the examination of base flow in two major rivers and by the development of a cross-sectional ground-water flow model.

\section{Purpose and Scope}

This report presents the results of the crosssectional analysis subproject of the Midwestern Basins and Arches RASA project. Specifically, this report addresses hydrogeologic aspects along a regional flow path including:

1. quantities and locations of recharge and discharge within the ground-water flow system,

2. the apportionment of ground-water flow between the surficial and carbonate-rock aquifers,

3. quantities of sustained ground-water discharge to the Scioto and Blanchard Rivers and to Sandusky Bay, and

4. ground-water pathlines and traveltimes.

\section{Previous Investigations}

The hydraulic properties of the carbonate-rock aquifer in northwest Ohio were studied by the Ohio Department of Natural Resources (ODNR), Division of Water, and described in "The Northwest Ohio Water Development Plan" (Ohio Department of Natural Resources, 1970); in the ODNR study, 76 large-diameter wells were drilled and tested to determine aquifer transmissivity. The hydrogeology of Sandusky County, Ohio, which borders Lake Erie at the north end of the regional flow path, was studied by Breen and Dumouchelle (1991).

\section{Hydrogeologic Setting}

The Appalachian, Illinois, and Michigan Basins and the Cincinnati, Kankakee, and Findlay Arches (fig. 1) are regional synclines and anticlines, respectively, that were produced by large-scale deformation of sedimentary rocks of Ordovician through Permian age. Erosion has nearly leveled the arches, exposing older rocks along the crests and progressively younger rocks laterally, toward the major structural basins.

The Midwestern Basins and Arches RASA study area has a humid, temperate climate. Mean annual precipitation within the Midwestern Basins and Arches study area, computed from stations with 50 or more years of record, ranges from 32 to $44 \mathrm{in} / \mathrm{yr}$. Mean annual precipitation near the regional flow path ranges from 33 to $36 \mathrm{in} / \mathrm{yr}$ (E.F. Bugliosi, U.S. Geological Survey, written commun., 1993).

The regional flow path (fig. 2) begins at a topographic, bedrock, and potentiometric high in central-western Ohio, an area of regional recharge; the flow path ends in Sandusky Bay, an area of regional discharge and part of the northeast boundary of the regional aquifer system. The flow path approximately follows the crest of the Findlay Arch, a regional anticline that strikes northeast, separating the Appalachian Basin to the southeast from the Michigan Basin to the northwest (fig. 1). This regional flow path was selected because (1) it includes distinct regional recharge and discharge areas for application as hydrologic boundaries, (2) a substantial amount of hydrologic data proximate to it were available, and (3) little was known about regional discharge into Lake Erie.

A synoptic water-level survey of 450 wells in the study area was done during the summer of 1990 to define the potentiometric surface within the carbonate bedrock (S.M. Eberts, U.S. Geological Survey, written commun., 1993). Hydraulic gradients and ground-water flow directions can be inferred from the potentiometric surface. The regional flow path was drawn perpendicular to the potentiometric contours of the carbonate-rock 


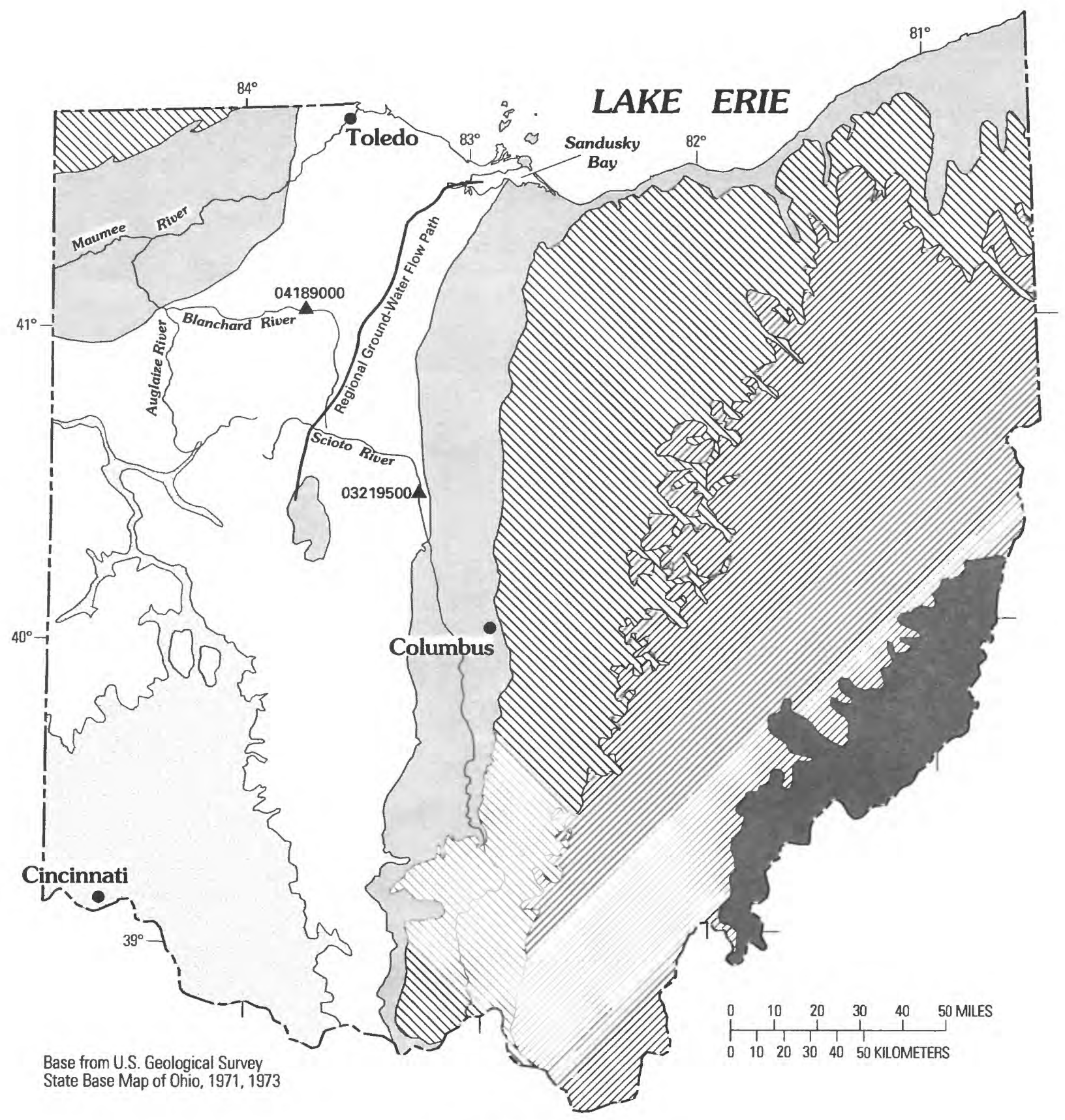

EXPLANATION

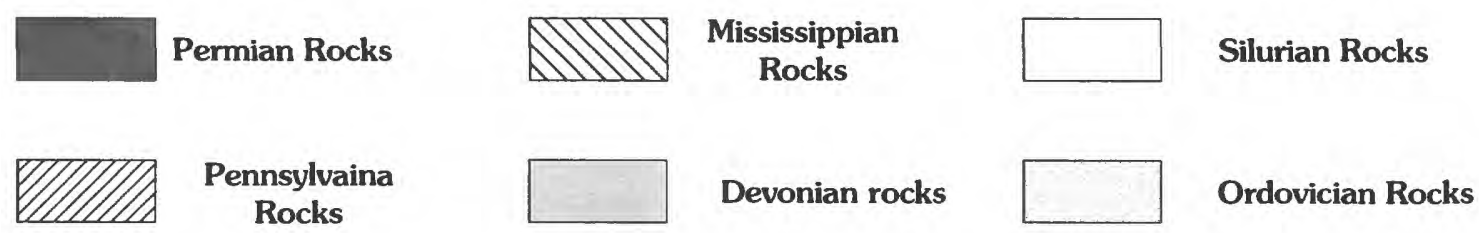

03219500 Streamflow-gaging station--Number is U.S. Geological Survey downstream-order number

Figure 2. Generalized bedrock geology of Ohio, location of streamflow-gaging stations used in hydrograph separation, and the regional flow path. 
aquifer (fig. 3). Water levels in the carbonate-rock aquifer, which were synoptically measured in 1990 , were contoured at intervals of $20 \mathrm{ft}$. These contours were used to delineate the southern $60 \mathrm{mi}$ of the regional flow path. Contours from Breen and Dumouchelle (1991) were used to delineate the northern $20 \mathrm{mi}$ of the regional flow path.

The topographic high at the south end of the regional flow path is a bedrock monadnock overlain by glacial deposits. The bedrock downgradient from the monadnock was peneplaned and incised by rivers before the Pleistocene glaciation (Fenneman, 1938). The present land surface is mostly flat to gently rolling except in the area of the monadnock, where topographic relief increases. Northward from the topographic high along the regional flow path, land-surface altitude initially decreases $400 \mathrm{ft}$ within $18 \mathrm{mi}$ and then decreases only $360 \mathrm{ft}$ in the remaining $62 \mathrm{mi}$ to Sandusky Bay.

Glaciers eroded topographic highs, buried river valleys, and deposited a wide variety of sediments along the regional flow path. These glacial sediments mantle the bedrock along the entire regional flow path. The glacial deposits have been generally categorized as end moraines, ground moraines, glaciolacustrine plains, and kames and eskers (Goldthwait and others, 1979) (fig. 4). The regional flow path begins in an end moraine and crosses four end moraines, five ground moraines, and one glaciolacustrine plain before it ends in Sandusky Bay (fig. 4). The end moraines are hummocky ridges that are higher than the adjacent terrain, the ground moraines are flat to gently undulating, and the glaciolacustrine deposits are very flat (Pavey and Goldthwait, 1993).

\section{Surficial Aquifers}

In general, the glacial deposits along the regional flow path are only locally considered a source of ground water. These deposits range in thickness from 3 to $100 \mathrm{ft}$ along the regional flow path and are mostly clay-rich tills containing small scattered lenses of sand and gravel. The water table generally is within the glacial deposits. Where the glacial deposits are very thin, the water table is in the carbonate bedrock, and the carbonate-rock aquifer is unconfined. Few wells are completed in the glacial deposits in the vicinity of the regional flow path because yields to wells in these deposits are generally insufficient, even for domestic use. Hydraulic conductivities of these deposits can differ by several orders of magnitude within the same type of deposit because of areal and vertical variations in composition, continuity, and structure (Bugliosi, 1990). The rate of groundwater flow in these deposits and the vertical leakage of ground water into the carbonate bedrock are affected by the differences in hydrologic properties of these various glacial deposits.

Regionally, the surficial aquifers are unconfined. Locally, however, transmissive layers at depth are confined by less permeable material (Strobel, 1993). Preglacial bedrock valleys filled with sand and gravel are more transmissive than most other types of glacial deposits. Wells in these sand and gravel deposits can yield as much as $500 \mathrm{gal} / \mathrm{min}$ (Breen and Dumouchelle, 1991).

\section{Carbonate-Rock Aquifer}

The carbonate-rock aquifer ranges in thickness from 260 to $600 \mathrm{ft}$ along the regional flow path and is generally confined by the overlying, mostly finegrained glacial and glaciolacustrine deposits. The contact between the carbonate bedrock and the glacial deposits is commonly a zone of fractured rock (Forsyth, 1968). Most domestic wells pump water from the uppermost part of the bedrock.

Silurian and Devonian limestone and dolomite compose the carbonate-rock aquifer along the regional flow path. The carbonate bedrock has relatively little intragranular porosity (primary porosity), and flow is controlled by the fracture, joint, and solution-channel-network geometry (secondary porosity). A wide variety of sedimentary textures and structures, ranging from fine bedding planes to massive reef-bank deposits, are found in these rocks (Textoris and Carozzi, 1966; Janssens, 1977; Shaver, 1991). The hydraulic conductivity of the carbonate-rock aquifer varies spatially as indicated by the wide range of transmissivities that were calculated from aquifer tests (Ohio Department of Natural Resources, 1970).

Transmissivity of the carbonate-rock aquifer is variable due to lithologic differences, physical and chemical weathering, and fractures. This variability has been brought about because of the complex deposition and erosion environments 


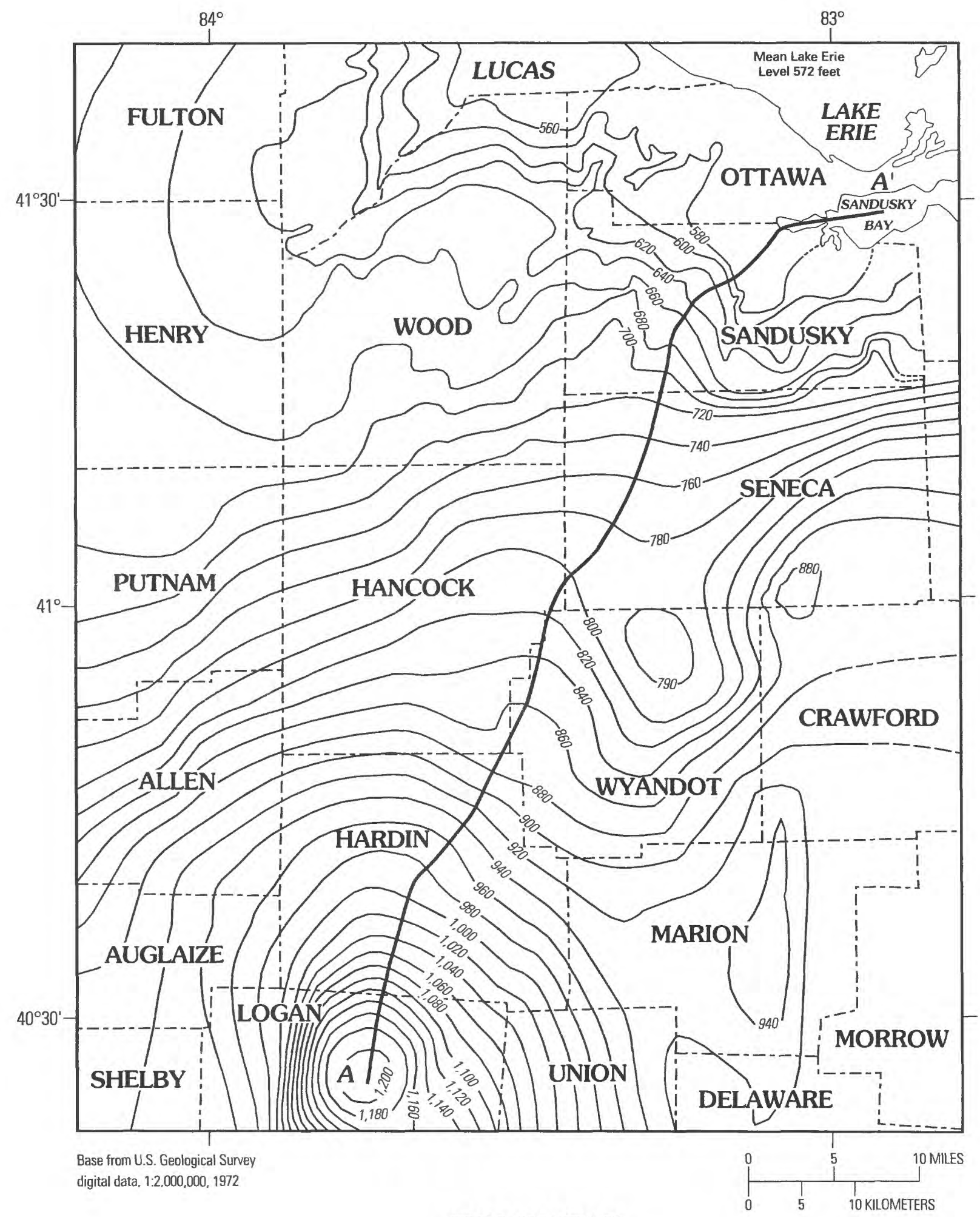

EXPLANATION

-980- - POTENTIOMETRIC CONTOUR-Shows altitude at which water level would have stood in tightly cased wells. Dashed where approximately located. Contour interval 20 feet, Datum is sea level

$A \longrightarrow A^{\prime}$ REGIONAL FLOW PATH

Figure 3. Potentiometric surface of the carbonate-rock aquifer in central-western and northwestern Ohio (drawn from data collected in July 1990 and from Breen and Dumouchelle, 1991) and the regional flow path. 


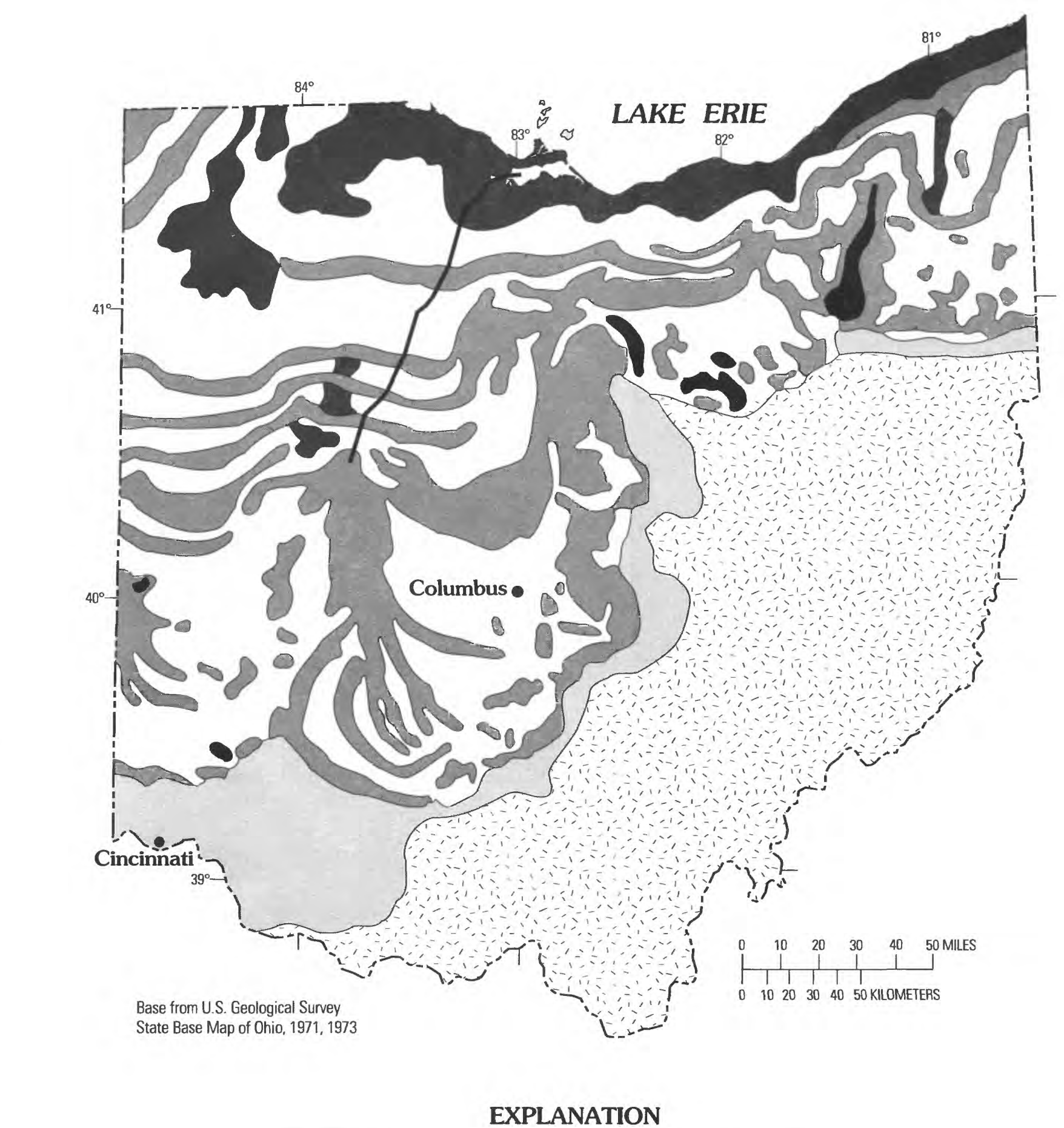

\section{EXPLANATION}

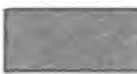

End moraine

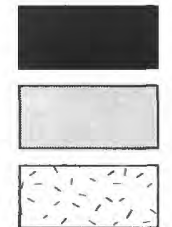

Kames and eskers

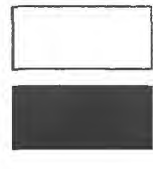

Ground moraine

Undifferentiated

Glaciolacustrine plain

Unglaciated

Regional flow path

Figure 4. Generalized glacial deposits of Ohio (modified from Goldthwait and others, 1979) and the regional flow path. 
produced by sea-level changes in Silurian and Devonian seas (Ohio Department of Natural Resources, 1970) and by postdiagenetic fracturing resulting from crustal stresses associated with regional bedrock deformation. In addition, isostatic forces associated with glaciation may have partly contributed to crustal stresses and related bedrock fracturing.

The major sedimentary rock units that make up the carbonate-rock aquifer along the regional flow path are the Brassfield Limestone/Cataract Group (Lower Silurian), Dayton Limestone (Middle Silurian), Lockport Dolomite (Middle Silurian), Salina Formation (Upper Silurian), Detroit River Group (Middle Devonian), Columbus Limestone (Middle Devonian), and Traverse Formation (Middle Devonian) (Casey, 1992) (fig. 5). Undifferentiated Cincinnatian rocks (Upper Ordovician) underlie the aquifer. A major unconformity is present between the Salina Formation and the Detroit River Group. The bedrock surface was previously overlain by Upper Silurian and Devonian carbonates and shales that have been removed by erosion except near the regional topographic high.

\section{ANALYSIS OF GROUND-WATER FLOW}

Streamflow data for two major rivers that cross the regional flow path [Scioto and Blanchard Rivers (fig. 2)] were analyzed by use of hydrograph-separation techniques and base-flowduration curves to estimate quantities of base flow in these rivers. A finite-difference, ground-water flow model (McDonald and Harbaugh, 1988) was used to simulate cross-sectional ground-water flow. A cross-sectional model was chosen to (1) test concepts of ground-water flow, such as locations of recharge and discharge, that could be applied to an areal ground-water flow model of the study area, and (2) provide ground-water traveltimes that could be compared to isotopic age-dating of ground water from selected wells near the regional flow path. The ground-water flow model was developed from available hydrologic and geologic data, such as static water levels and lithologic thicknessies collected from USGS and ODNR data bases. Hydraulic heads and quantities of cell-to-cell flow from model output were then used as input to a ground-water particle-tracking postprocessor (Pollock, 1989) that computes ground-water pathlines and traveltimes.

\section{Base-Flow Analysis}

Base flow is stream discharge that is not attributable to direct runoff from precipitation or melting snow. It is usually maintained by ground-water discharge. Base-flow analysis was used to estimate amounts of discharge from the ground-water flow system to the Scioto and Blanchard Rivers. Because steady-state conditions exist along the regional flow path, discharge from the ground-water flow system must equal recharge to the ground-water flow system. Therefore, base-flow analysis was also used to estimate recharge to the ground-water flow system along the regional flow path.

Streamflow hydrographs for the Scioto and Blanchard Rivers were separated into components of base flow and runoff. The effects of short-term bank-storage discharge after high flows were minimized by use of the local minimun method of hydrograph separation (Pettyjohn and Henning, 1979). In this method, the lowest points on streamflow hydrographs are connected, and base flow is identified as the component of streamflow below the line connecting these points. Average rates of recharge to the ground-water flow system were estimated by dividing the base flow calculated for each station by the drainage area of the basin (table 1).

Mean base flows of the Scioto and Blanchard Rivers during the driest periods (periods of least recharge) were estimated by analysis of base-flowduration curves (S.M. Eberts, U.S. Geological Survey, written commun., 1993). Base-flowduration curves are cumulative frequency curves that show the percentage of time that specific base flows were equaled or exceeded in a given period of time. The slopes of base-flow-duration curves for the Scioto River near Prospect, Ohio, and the Blanchard River near Findlay, Ohio, begin to flatten at about 75 percent (fig. 6). Base flows equaled or exceeded 75 percent of the time likely correspond to periods, normally during late summer or during drought, when discharge from shallow parts of the ground-water system has 


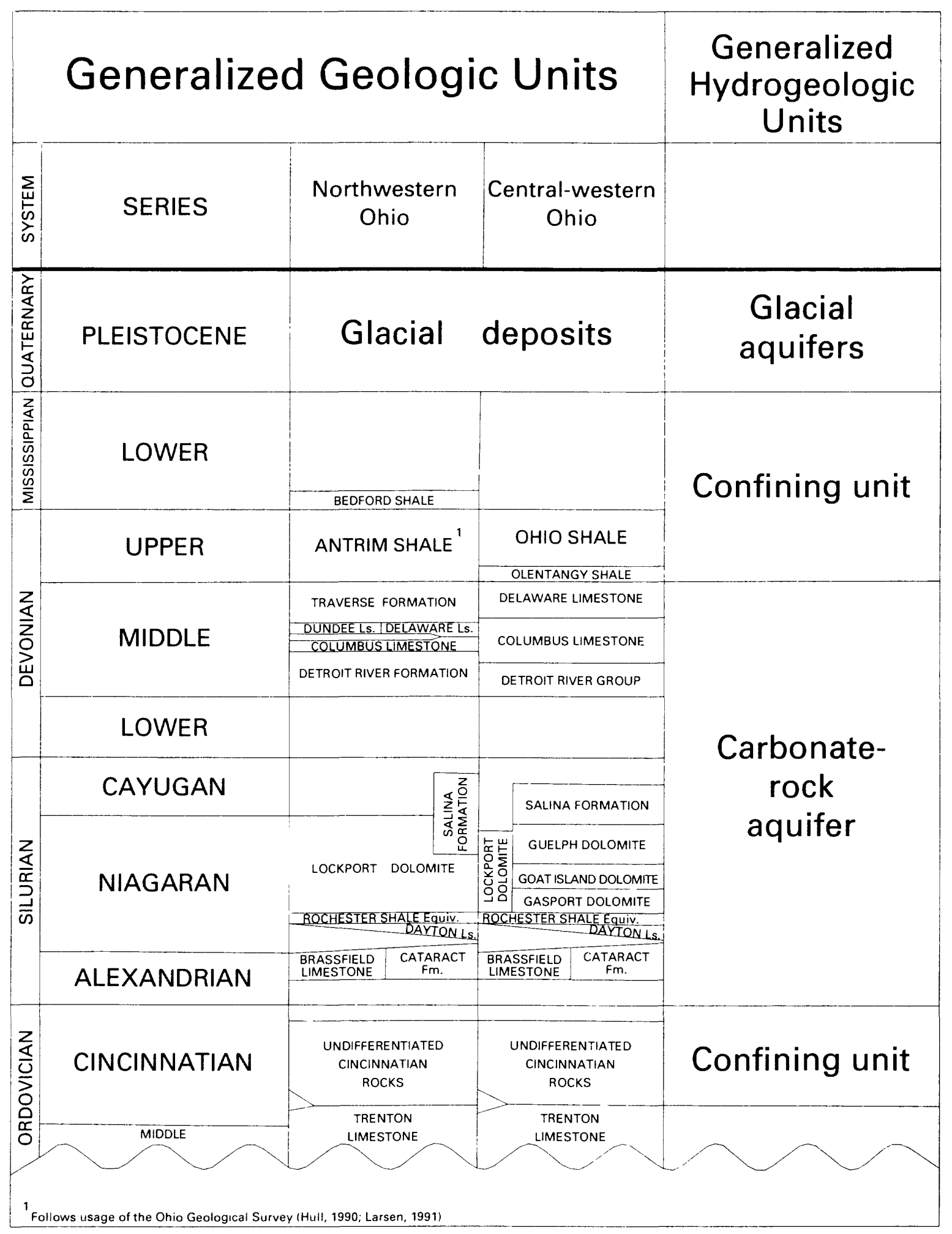

Figure 5. Relation between geologic and hydrogeologic units in central-western and northwestern Ohio.

diminished and discharge from deeper parts of the ground-water system sustains the base flow in these rivers. The mean value of base flow below the inflection point on the graph for each surface- water basin was assumed to be the mean rate of sustained ground-water discharge to that basin.

The mean rate of sustained ground-water discharge per foot of river reach for each river was 
Table 1. Average annual recharge to the ground-water flow system within the Scioto and Blanchard River Basins, Ohio, as estimated from hydrograph separation

$\left[\mathrm{ft}^{3}\right.$, cubic feet; $\mathrm{ft}^{2}$, square feet; $\mathrm{ft}, \mathrm{feet} ; \mathrm{in} / \mathrm{yr}$, inches per year]

\begin{tabular}{lccccc}
\hline Basin & $\begin{array}{c}\text { Station } \\
\text { number }\end{array}$ & $\begin{array}{c}\text { Years of } \\
\text { record }\end{array}$ & $\begin{array}{c}\text { Estimated annual } \\
\text { base flow }\left(\mathrm{ft}^{3}\right)\end{array}$ & $\begin{array}{c}\text { Drainage basin } \\
\text { area }\left(\mathrm{ft}^{2}\right)\end{array}$ & $\begin{array}{c}\text { Estimated annual } \\
\text { recharge }(\mathrm{ft})\end{array}$ \\
\hline Scioto River & 03219500 & 65 & $4.93 \times 10^{9}$ & $1.58 \times 10^{10}$ & $0.31(3.72 \mathrm{in} / \mathrm{yr})$ \\
Blanchard River & 04189000 & 66 & $2.20 \times 10^{9}$ & $9.65 \times 10^{9}$ & $.23(2.76 \mathrm{in} / \mathrm{yr})$ \\
\hline
\end{tabular}

assumed to be constant for each foot of river reach upgradient from the gaging stations considered in this analysis. For model calibration, a mean rate of sustained ground-water discharge per foot of river reach was calculated for the Scioto and Blanchard Rivers by dividing the estimated rate of sustained ground-water discharge for each surface-water basin by the total length of perennial river within that basin (table 2).

\section{Conceptual Model of Ground-Water Flow}

Major elements of a conceptual model of ground-water flow along the regional flow path include location of net recharge and discharge, depth of flow, and ground-water/surface-water interaction. Ground-water flow can be classified as local, intermediate, or regional (Toth, 1963). These terms of scale are relative, and their definition depends on the scale at which ground-water flow is studied. For this study, ground water in the local-flow subsystem follows short, shallow pathlines from point of recharge to point of discharge. Ground water in the intermediate-flow subsystem follows longer and somewhat deeper pathlines than ground water in the local-flow subsystem and flows under at least one local-flow subsystem. Ground water in the regional-flow subsystem follows the longest, deepest pathlines, enters the flow system at major topographic highs or divides, flows under interbasin surface-water divides, and discharges into major rivers and Sandusky Bay. In this report, sustained ground-water discharge is considered to be discharge from the intermediate- and regionalflow subsystems. Ground water from the intermediate- and regional-flow subsystems sustains base flow in major rivers and lakes after ground-water levels have declined during periods of little precipitation.

Theoretically, patterns of ground-water flow of an aquifer system are affected by depth-to-lateralextent ratio, water-table configuration, stratigraphy, and subsurface variations in permeability (Freeze and Witherspoon, 1967). A generalized conceptual hydrologic section along the regional flow path is shown in figure 7 .

Water recharges the ground-water system at the water table in topographically high areas and discharges from the water table in topographically low areas. In an area of gaining streams, such as central-western and northwestern Ohio, groundwater discharge from the aquifer system is generally proportional to the total length of perennial streams within a given area. Generally, the glacial deposits have a lower vertical hydraulic conductivity than the carbonate bedrock and thus restrict recharge to and discharge from the bedrock.

In the natural system, ground-water flow deviates somewhat from the trend of the regional flow path; however, cross-sectional numeric models of ground-water flow are of unit width by convention. Therefore, the cross-sectional model was developed to represent average hydrologic conditions within a corridor that is arbitrarily $3-\mathrm{mi}$ wide and centered on the regional flow path.

\section{Simulation of Ground-Water Flow}

The partial differential equation governing steady-state ground-water flow is a combined form of Darcy's law and the continuity equation (Wang and Anderson, 1982), written as 

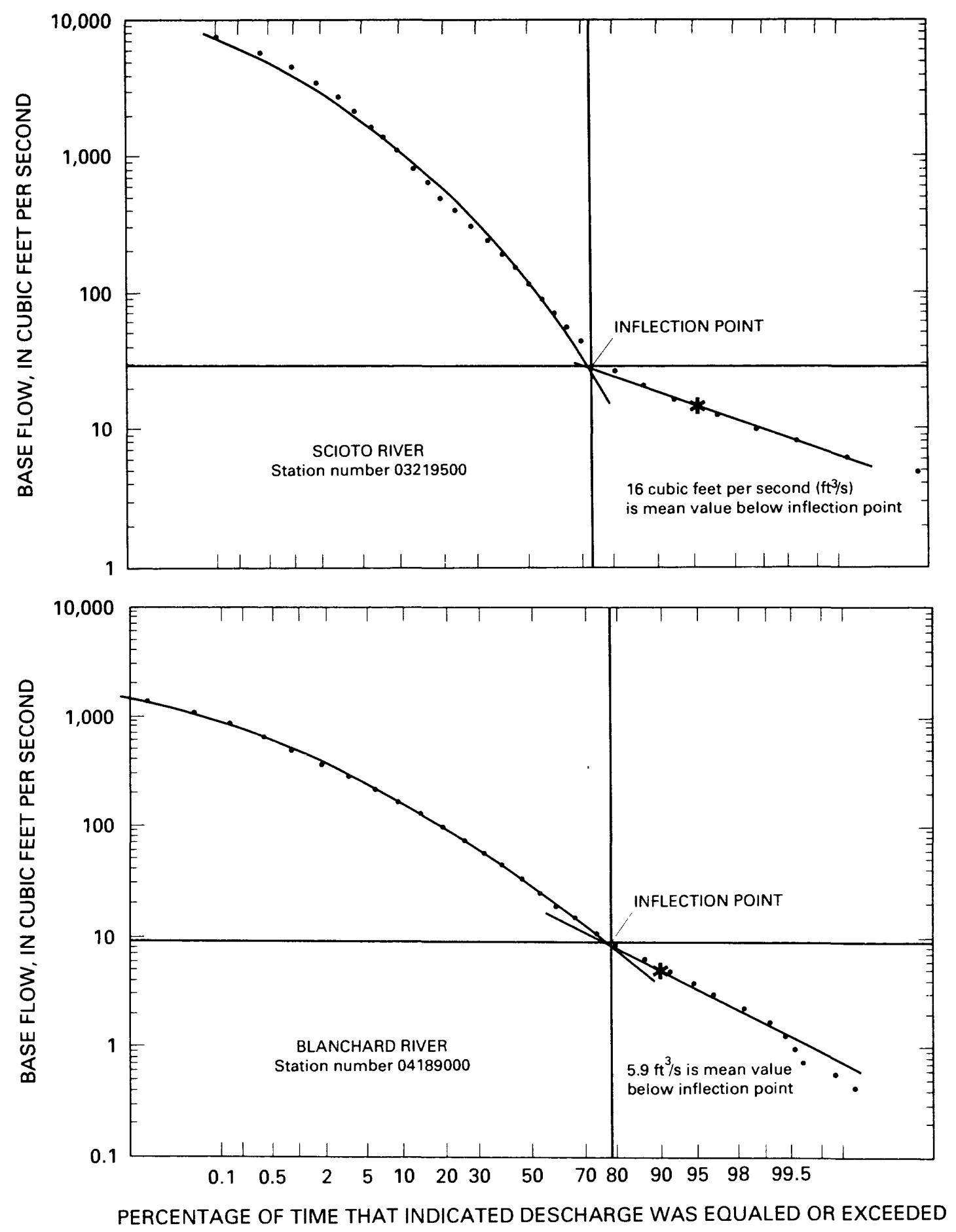

Figure 6. Base-flow-duration curves for the Scioto River Basin near Prospect, Ohio, and the Blanchard River Basin near Findlay, Ohio. 
Table 2. Sustained ground-water discharge per foot of river reach to the Scioto and Blanchard Rivers, Ohio, as estimated from analysis of base-flow-duration curves

\begin{tabular}{|c|c|c|c|}
\hline \multicolumn{4}{|c|}{ [ft $\mathrm{ft}^{3} \mathrm{~s}$, cubic feet per second; $\mathrm{ft}$, feet] } \\
\hline Basin & $\begin{array}{c}\text { Estimated } \\
\text { ground-water } \\
\text { discharge per } \\
\text { basin }\left(\mathrm{ft}^{3} / \mathrm{s}\right)\end{array}$ & $\begin{array}{l}\text { Perennial } \\
\text { river length } \\
\text { per basin ( } f t)\end{array}$ & $\begin{array}{l}\text { Estimated } \\
\text { ground-water } \\
\text { discharge per } \\
\text { foot of river } \\
\left(\mathrm{ft}^{3} / \mathrm{s}\right)\end{array}$ \\
\hline Scioto River & 16.0 & $1,363,084$ & $1.2 \times 10^{-5}$ \\
\hline Blanchard River & 5.9 & 936,821 & $6.3 \times 10^{-6}$ \\
\hline
\end{tabular}

$$
\frac{\partial}{\partial x}\left(-K_{x} \frac{\partial h}{\partial x}\right)+\frac{\partial}{\partial y}\left(-K_{y} \frac{\partial h}{\partial y}\right)+\frac{\partial}{\partial z}\left(-K_{z} \frac{\partial h}{\partial z}\right)=0
$$

where $x, y$, and $z$ are the three directional variables;

$K_{x}, K_{y}$ and $K_{z}$ are the hydraulic conductivities of the aquifer media in the $x-, y$, and $z$-directions; and

$h$ is the hydraulic head in the aquifer at the point (or node) where the equation is solved.

Flow in the $x$-direction is along the trend of the regional flow path. Flow in the $y$-direction is perpendicular to the trend of the regional flow path and is assumed to be zero for this simulation. A cross section of the aquifer system along the regional flow path was simulated with a steadystate model 80 columns long and 1 row wide. The section was simulated as two model layers; the glacial deposits (layer 1) were simulated as unconfined, and the underlying carbonate bedrock (layer 2) was simulated as confined. Although the carbonate-rock aquifer is composed of several geologic formations with varying lithologies, it is considered a single hydraulic unit (model layer) in this study because vertical hydraulic gradients are relatively small in the carbonate-rock aquifer (Arihood, 1994) and flow is predominately horizontal.

Both model layers were discretized into 80 cells. Beginning at the south end of the regional flow path, the first 48 cells in both layers were $1.25 \mathrm{mi}$ long and the last 32 cells were $0.625 \mathrm{mi}$ long. The last 32 cells were the most finely discretized to allow for additional detail near Sandusky Bay, where regional ground-water pathlines converge. All cells were a unit width of $1 \mathrm{ft}$. The final 8 cells represented Sandusky Bay (fig. 3). Saturated cell thicknesses ranged from 260 to $600 \mathrm{ft}$ for model layer 2 representing the carbonate-rock aquifer and from 0 to $97 \mathrm{ft}$ for model layer 1 representing the glacial deposits. A schematic section showing horizontal and vertical model discretization is shown in figure 8.

\section{Assumptions}

Two-dimensional, steady-state flow within a saturated, isotropic, homogeneous material was assumed for the glacial deposits and the carbonate bedrock along the regional flow path. The joints, fractures, and solution channels through which ground water flows in the carbonate bedrock were assumed to be interconnected to the extent that the carbonate bedrock can be considered homogeneous and isotropic.

All ground-water levels in the USGS GroundWater Site Inventory (GWSI) data base for the counties surrounding the regional flow path were examined to determine whether long-term transient or steady-state conditions best represent the ground-water system. Fluctuating water levels can indicate transient conditions, whereas fairly constant water levels usually indicate steady-state conditions. Although water levels in a few wells in karstic areas of eastern Sandusky County fluctuated seasonally by as much as $12 \mathrm{ft}, 98$ percent of water levels fluctuated less than $5 \mathrm{ft}$ during 1940-93. This amount of fluctuation can be attributed to seasonal variations in recharge. For modeling, ground-water levels and velocities at any point in the flow system were assumed to be constant with time (steady state), and recharge to and discharge from the system were assumed to be equal. 


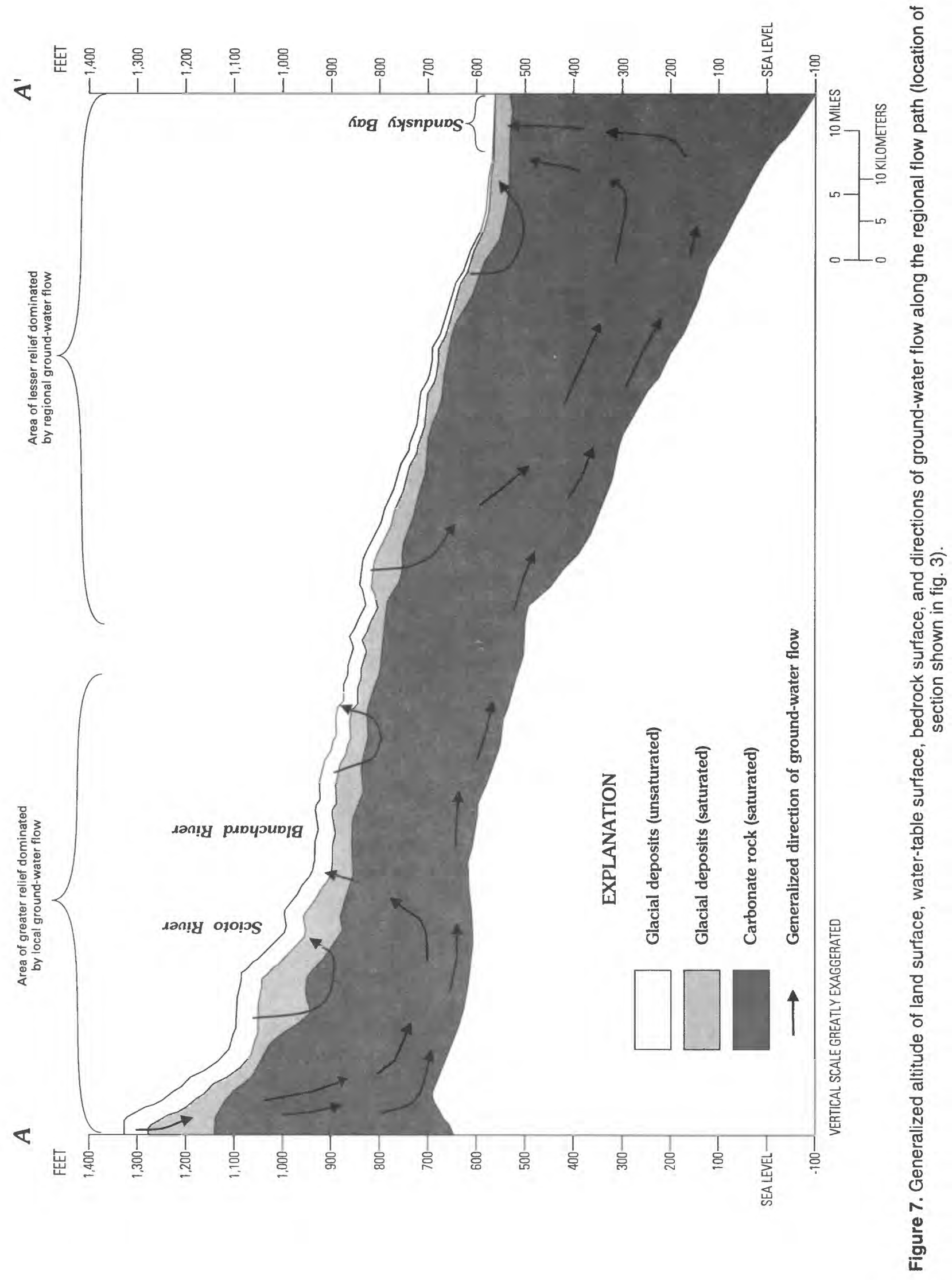




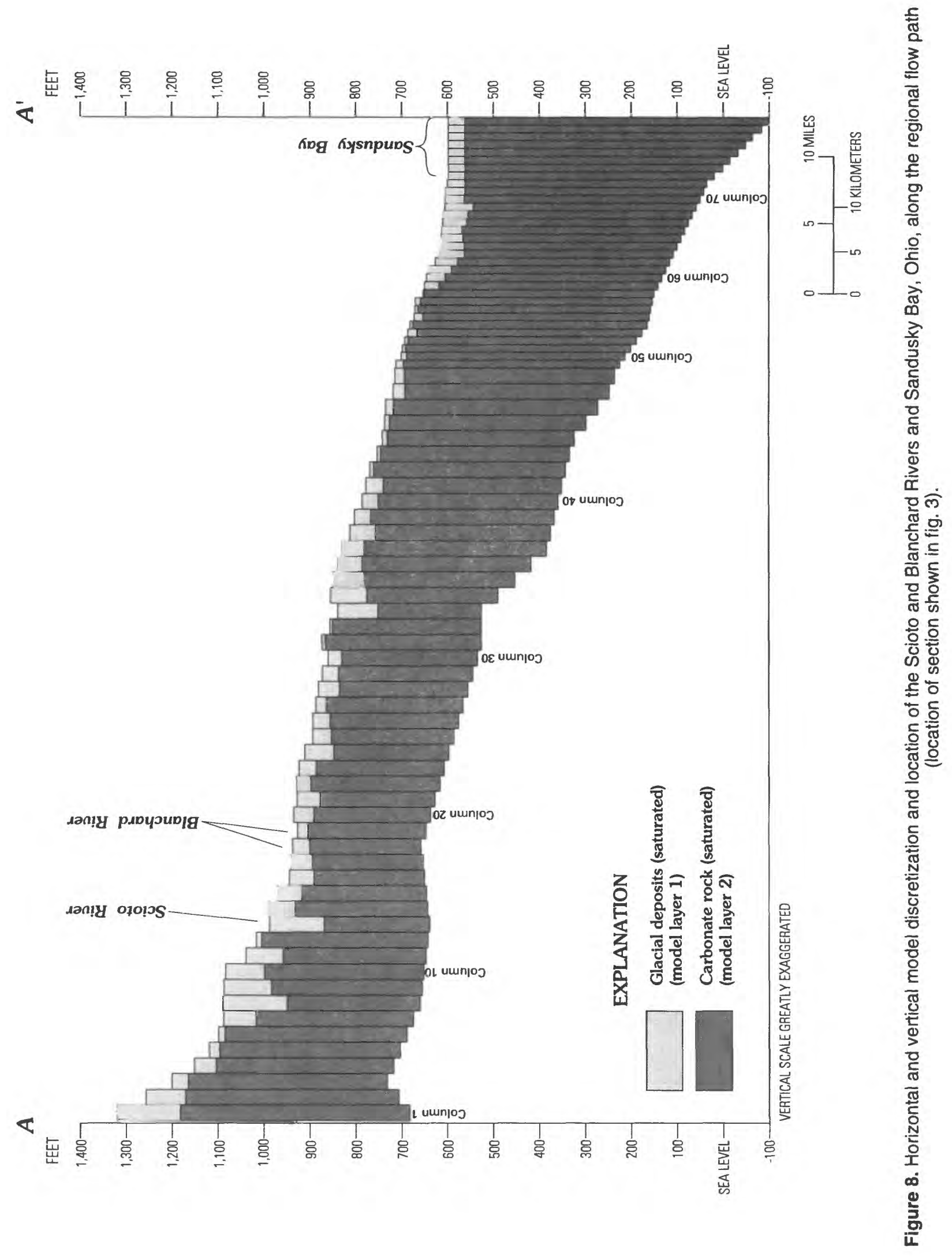


Additional assumptions and simplifications necessarily incorporated into the ground-water flow model included the following:

(1) The carbonate-rock aquifer was confined by the overlying glacial deposits.

(2) All streams in the vicinity of the regional flow path received base flow from the ground-water system.

(3) Average water-table altitudes for cells in layer 1 approximated average stream stages.

(4) The effective thickness of the riverbeds in the Scioto and Blanchard Rivers and the lakebed in Sandusky Bay was $1 \mathrm{ft}$.

\section{Boundaries}

The upper surface of layer 1 (the water-table boundary) combines the effects of ground-water recharge from precipitation and ground-water discharge to streams (Buxton and Modica, 1992). This physical relation was simulated in the model by applying recharge and general-head boundaries to the upper surface of layer 1. Water-table altitudes were used as general-head boundary heads to simulate the regional water-table surface. The general-head boundaries were also used to simulate ground-water discharge from the water table to streams in proportion to stream density near cells that did not represent the Scioto or Blanchard Rivers. The Scioto and Blanchard Rivers were simulated as river boundaries. The general-head boundaries and the river boundaries are both internal, head-dependent-flux boundaries (McDonald and Harbaugh, 1988). The model calculates flow between the aquifer system and surface-water bodies for these boundaries by means of specified hears and conductance terms.

Ground-water seepage into lakes that are wider than the thickness of their underlying surficial deposits (which is the case for Lake Erie) tends to be concentrated near the shore (Freeze and Cherry, 1979). A study of ground-water discharge into Lake St. Clair (fig. 1), approximately $70 \mathrm{mi}$ north of Sandusky Bay, indicated that seepage is within a zone that extends no farther than about $10,000 \mathrm{ft}$ from shore (Anderson, 1987). Accordingly, Sandusky Bay was considered a regional groundwater discharge area, and the north end of the model, which represents the limit of ground-water flow into the bay, was simulated as a no-flow boundary.

The south end of the regional flow path was simulated as a no-flow boundary because it is coincident with a regional ground-water divide (fig. 3). The top of the Ordovician bedrock was simulated as a no-flow boundary because the Ordovician bedrock is composed of fine-grained shale and argillaceous limestone that impedes ground-water flow (Casey, 1992). The top of the Ordovician bedrock is considered to be the lower confining surface for the carbonate-rock aquifer throughout the study area. The sides of the model were simulated as no-flow boundaries because, by definition, there is no flow orthogonal to a flow path.

\section{Calibration}

Hydrologic parameters in the model were adjusted within reasonable limits until simulated hydraulic heads in layer 2 and simulated groundwater discharge to the Scioto and Blanchard Rivers approximated measured or estimated values. Hydrologic parameters in the model included recharge, horizontal hydraulic conductivity of layer 1 , transmissivity of layer 2 , vertical leakance between layers 1 and 2, riverbed vertical hydraulic conductivity, lakebed (Sandusky Bay) vertical hydraulic conductivity, and general-head-boundary conductance.

The average areal recharge rate calculated from hydrograph separation of streamflow data from the Scioto and Blanchard River Basins was $7.4 \times 10^{-4} \mathrm{ft} / \mathrm{d}(3.24 \mathrm{in} / \mathrm{yr})$. This average areal recharge rate was applied to layer 1 in the model; however, recharge values were zoned according to the permeability of the glacial deposits. Recharge applied to end morainal areas, which contain lenses of sand and gravel, was $1.3 \times 10^{-3} \mathrm{ft} / \mathrm{d}(5.69 \mathrm{in} / \mathrm{yr})$. Recharge was reduced where the glacial deposits were less permeable (and more runoff was expected); $8.0 \times 10^{-4} \mathrm{ft} / \mathrm{d}(3.50 \mathrm{in} / \mathrm{yr})$ was applied to ground morainal areas, and $5.9 \times 10^{-4} \mathrm{ft} / \mathrm{d}$ ( $2.58 \mathrm{in} / \mathrm{yr}$ ) was applied to glaciolacustrine areas. Total recharge to the unit-width model was approximately $322 \mathrm{ft}^{3} / \mathrm{d}$.

The horizontal hydraulic conductivities for glacial deposits in Ohio at wells for which slug-test data are available range from 0.33 to $1,000 \mathrm{ft} / \mathrm{d}$ 
(Joseph and Eberts, 1994). The horizontal

hydraulic conductivity of cells in layer 1 was zoned according to the glacial deposit simulated: $10 \mathrm{ft} / \mathrm{d}$ was applied to areas of end moraine deposits, which contain lenses of sand and gravel; $5 \mathrm{ft} / \mathrm{d}$ was applied to areas of ground moraine deposits, which are generally finer grained than end moraine deposits; and $1 \mathrm{ft} / \mathrm{d}$ was applied to areas of glaciolacustrine deposits, which are very fine grained.

The reported transmissivities for the carbonate bedrock (layer 2) range from 70 to about $25,000 \mathrm{ft}^{2} / \mathrm{d}$ for 76 wells tested (Ohio Department of Natural Resources, 1970); the median is $1,650 \mathrm{ft}^{2} / \mathrm{d}$, and the interquartile range is from 850 to $3,700 \mathrm{ft}^{2} / \mathrm{d}$. Seven of these wells were within $1 \mathrm{mi}$ of the regional flow path, and transmissivities at these wells range from 540 to $4,550 \mathrm{ft}^{2} / \mathrm{d}$; the median is $1,200 \mathrm{ft}^{2} / \mathrm{d}$, and the interquartile range is from 850 to $3,000 \mathrm{ft}^{2} / \mathrm{d}$. Transmissivities input to layer 2 of the model were calculated by multiplying saturated thicknesses of the carbonaterock aquifer for each cell in layer 2 by $9 \mathrm{ft} / \mathrm{d}$, the geometric mean of effective carbonate bedrock horizontal hydraulic conductivity for the study area (S.M. Eberts, U.S. Geological Survey, written commun., 1993). The resulting transmissivities ranged from 2,475 to $5,400 \mathrm{ft}^{2} / \mathrm{d}$.

The vertical leakance between layers 1 and 2 is calculated from an input parameter, Vcont (McDonald and Harbaugh, 1988), which is vertical conductance divided by cell area. Vcont is calculated as

$$
\text { Vcont }=\frac{1}{\frac{\left(\Delta V_{1}\right) / 2}{K_{: 1}}+\frac{\left(\Delta V_{2}\right) / 2}{K_{: 2}}},
$$

where $\Delta V_{\mathrm{l}} \quad$ is the thickness of model layer 1 (L);

$\Delta V_{2} \quad$ is the thickness of model layer 2 (L);

$K z 1 \quad$ is the vertical hydraulic conductivity of model layer 1 (L/T); and

$K \tilde{z}^{2} \quad$ is the vertical hydraulic conductivity of model layer 2 $(\mathrm{L} / \mathrm{T})$.

Laboratory determinations of vertical hydraulic conductivity from 13 core samples of glacial till in northern Ohio ranged from 0.0001 to $0.12 \mathrm{ft} / \mathrm{d}$ (Norris, 1962). Vertical leakance for each model column was calculated (1) by use of saturated thicknesses for layer 1 derived from drillers' logs for wells near the regional flow path, (2) under the assumption that vertical hydraulic conductivity of layer 1 is $0.001 \mathrm{ft} / \mathrm{d}$, (3) by use of saturated thicknesses for layer 2 derived from bedrock maps, and (4) under the assumption that vertical hydraulic conductivity of layer 2 is $0.9 \mathrm{ft} / \mathrm{d}$ (one order of magnitude less than the geometric mean of the effective carbonate bedrock horizontal hydraulic conductivity for the study area). A 75- to 100 -ft-thick shale bed that lies between the glacial deposits and the carbonate bedrock at model columns 1 and 2 was not simulated as a model layer but was included in the calculation of vertical leakance between layers 1 and 2 for these columns (the vertical hydraulic conductivity for the shale was assumed to be $0.0001 \mathrm{ft} / \mathrm{d}$ in this calculation).

Riverbed conductance $\left(C_{r i v}\right)$ was calculated as

$$
C_{\text {riv }}=\frac{K_{\text {riv }} A_{\text {riv }}}{M},
$$

where $K_{\text {riv }} \quad$ is the vertical hydraulic conductivity of the riverbed medium $(\mathrm{L} / \mathrm{T})$;

$A_{\text {riv }} \quad$ is the surface area of the river in the cell $\left(\mathrm{L}^{2}\right)$; and

$M \quad$ is the thickness of the riverbed (L).

Estimates of riverbed vertical hydraulic conductivity $\left(K_{\text {riv }}\right)$ were obtained for 22 sites on the Scioto River by use of seepage meters (W.L. Cunningham, U.S. Geological Survey, written commun., 1993) and ranged from 0.004 to $3.75 \mathrm{ft} / \mathrm{d}$. The highest and lowest of the riverbed vertical hydraulic conductivities $\left(K_{\text {riv }}\right)$ provided by Cunningham were used to calculate riverbed conductances $\left(C_{r i v}\right)$ for the Scioto and Blanchard Rivers. Riverbed conductance ranged from 0.24 to $225 \mathrm{ft} / \mathrm{d}$ for the Scioto River cell (layer 1, column 13) and from 0.12 to $113 \mathrm{ft} / \mathrm{d}$ for the Blanchard River cells (layer 1, columns 17 and 18). Riverbed conductance for these river cells were adjusted within this range until the discharge from these cells matched estimates of sustained discharge to these rivers. Calibrated riverbed conductance was $0.75 \mathrm{ft}^{2} / \mathrm{d}$ for the Scioto River cell and 0.38 and 
$0.48 \mathrm{ft}^{2} / \mathrm{d}$ for the Blanchard River cells; thus, calibrated riverbed vertical hydraulic conductivity was $0.0125 \mathrm{ft} / \mathrm{d}$ for the Scioto River and 0.0127 and $0.016 \mathrm{ft} / \mathrm{d}$ for the Blanchard River. Simulated sustained discharge was $1.07 \mathrm{ft}^{3} / \mathrm{d}$ to the Scioto River and $0.65 \mathrm{ft}^{3} / \mathrm{d}$ to the Blanchard River.

The lakebed in Sandusky Bay, where the model terminates, is composed of silt and clay. No measurements of vertical hydraulic conductivity are known for these sediments, but textbook hydraulic conductivities for clays range from $10^{-6}$ to $10^{-3} \mathrm{ft} / \mathrm{d}$ (Freeze and Cherry, 1979). Seepage data for Sandusky Bay are not available for use as calibration targets; however, modelsimulation results indicate that a lakebed vertical hydraulic conductivity of $10^{-6} \mathrm{ft} / \mathrm{d}$ results in ground-water discharge farther from shore than a lakebed vertical hydraulic conductivity of $10^{-3} \mathrm{ft} / \mathrm{d}$. As simulated vertical hydraulic conductivity of the lakebed is decreased, simulated ground-water discharge results farther from shore. Modelsimulation results also indicate that varying of lakebed vertical hydraulic conductivity has no appreciable effect on the quantity of ground water that discharges to Sandusky Bay or the hydraulic head at any point within the aquifer system. Simulated sustained discharge to the bay was $1.69 \mathrm{ft}^{3} / \mathrm{d}$ when lakebed vertical hydraulic conductivity was set to $10^{-3} \mathrm{ft} / \mathrm{d}$.

Base-flow data for calibration of ground-water discharge from the ground-water flow system to streams were not available except for cells that represented the Scioto and Blanchard Rivers. The accuracy of simulated ground-water discharge from cells where base-flow data were not available cannot be checked. Where base-flow data were not available, general-head boundaries were applied in layer 1 and general-head boundary conductances were set proportional to the total length of perennial streams measured within $1.5 \mathrm{mi}$ to either side of the regional flow path. Perennial stream lengths adjacent to each model column ranged from 525 to $32,635 \mathrm{ft}$.

Stream-length values (as general-head boundary conductances) were initially too large for the unit-width model and caused numerical instability in model simulation. During model calibration, general-head boundary conductances were reduced, maintaining the proportionality of stream lengths, until numerical stability was achieved. The general-head boundaries had the effect of holding hydraulic heads in layer 1 to within $1 \mathrm{ft}$ of estimated water-table altitudes for each cell in layer 1 while simulating ground-water discharges to streams that were approximately proportional to the general-head-boundary conductances. General-head-boundary conductances ranged from 10.50 to $65.26 \mathrm{ft}^{2} / \mathrm{d}$. Discharge from the general-head boundaries ranged from 0.20 to 15.27 to $^{3} / \mathrm{d}$. About 99 percent of groundwater discharge from the model was across the general-head boundaries.

Water-table altitudes for use as boundary heads in the general-head boundaries were estimated from static water levels from drillers' logs for wells that were completed in the glacial deposits near model columns 1 through 12 . No wells were completed in the glacial deposits near model columns 13 through 80 because the glacial deposits in this area cannot be pumped to obtain sufficient quantities of water. In humid states such as Ohio, the water table tends to generally follow land surface (Williams and Williamson, 1989); therefore, water-table altitudes for these columns were estimated by linear regression of land-surface altitudes on water-table altitudes for 50 wells that were completed in the glacial deposits in the counties through which the regional flow path passes (fig. 9). This regression produced a correlation coefficient of 0.99025 . The equation relating water-table altitude to land-surface altitude that was derived from the regression was

$$
Y=0.927212(X)+40.927 \text {, }
$$

where $\quad Y$ is the water-table altitude, in feet; and

$X$ is the land-surface altitude, in feet.

Land-surface altitudes were averaged over an area $3 \mathrm{mi}$ wide (1.5 mi to either side of each model column) and 1 column length long by use of USGS 7 1/2-minute topographic maps. These average land-surface altitudes for each column were then substituted into equation 2 to arrive at estimates of average water-table altitudes for use as boundary heads in the general-head boundaries.

Calibration targets for hydraulic head in 58 of the 80 cells in layer 2 were calculated from drillers' $\operatorname{logs}$ for wells that were cased through the surficial 


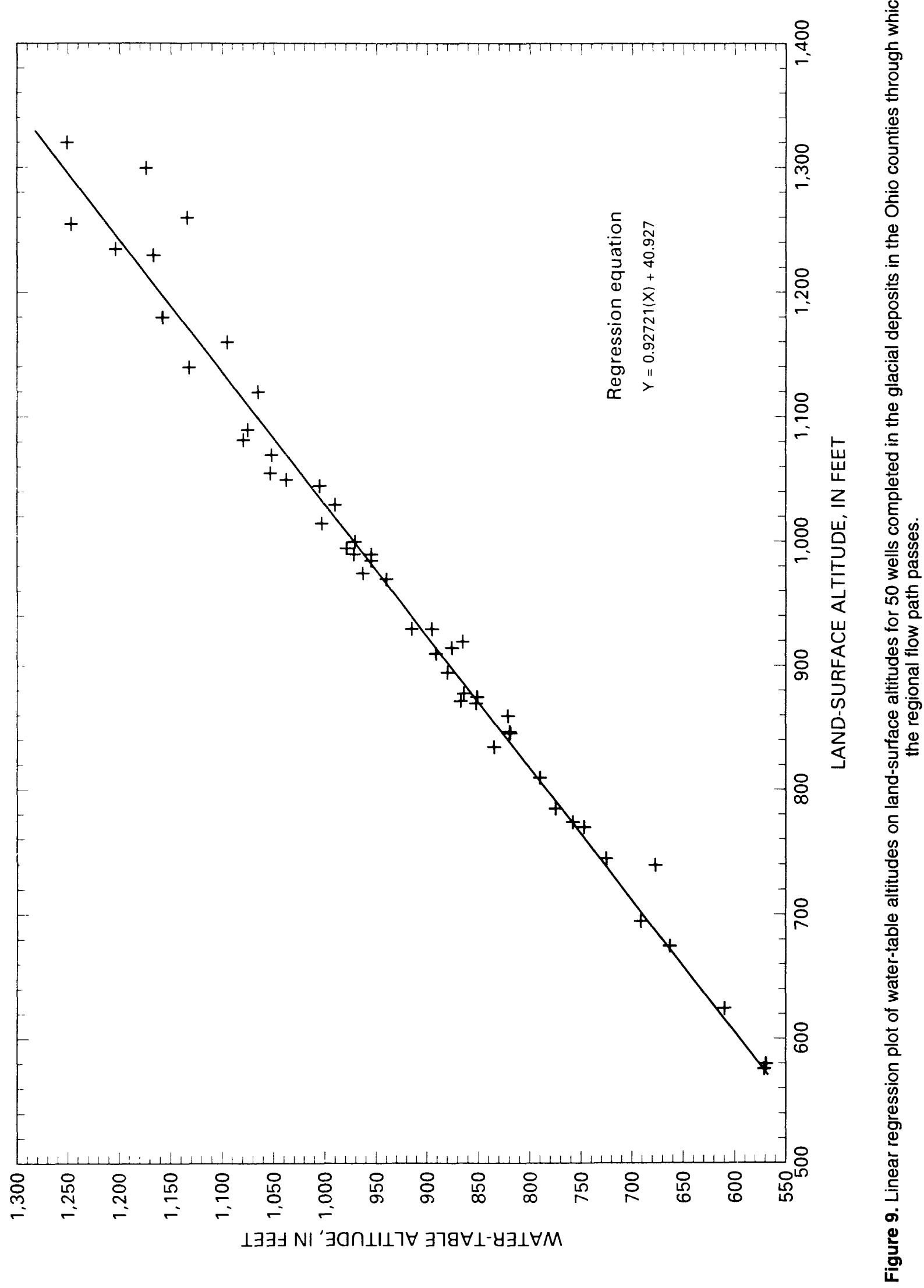


deposits and completed in the carbonate bedrock near the regional flow path. No hydraulic-head data were available for the remaining 22 cells in layer 2; thus calibration targets for hydraulic head for these cells were estimated by interpolation from the potentiometric surface (fig. 3). Simulated hydraulic heads in layer 2 were within $18 \mathrm{ft}$ of the calibration targets (fig. 10). The root-mean-square error (RMSE) of simulated heads compared to calibration targets accounts for variance of the compared data. RMSE was calculated as

$$
R M S E=\sqrt{\frac{\sum_{i=1}^{N}\left(h_{c a l_{t}}-h_{m_{t}}\right)^{2}}{N}},
$$

where $\quad h_{c a l}$ is the simulated hydraulic head;

$h_{m}$ is the calibration target (measured hydraulic head); and

$N$ is the number of calibration hydraulic heads used in error computations.

The term " $h_{c a l}-h_{m}$ " is known as the head difference or residual head. The RMSE in the calibrated model for simulated hydraulic heads in layer 2 was $7.3 \mathrm{ft}$.

\section{Sensitivity Analysis}

Certain model parameters are more sensitive than others for a particular ground-water system. An analysis ranked the effect that specific model parameters had upon the ability of the model to simulate actual geohydrologic conditions. Output from the calibrated model was used as a base to determine the sensitivity of specific parameters. One parameter array was varied within hydrologically reasonable limits while all other parameters were held constant for successive model runs. Parameter sensitivities could greatly differ among combinations of changes.

All calibrated model parameter arrays, except recharge, were varied by \pm 1 order of magnitude; an order-of-magnitude increase in recharge would have been unreasonable for accurate simulation of the aquifer system; thus, recharge was varied from -1 to +0.2 orders of magnitude. Head responses are reported as the percentage change in RMSE of head residuals (fig. 11). Model parameters, in order of decreasing sensitivity to changes in hydraulic head, were (1) transmissivity of layer 2 , (2) vertical leakance between layers 1 and 2, (3) general-head-boundary conductance, and (4) recharge. The sensitivity of head residuals to changes in the hydraulic conductivity of layer 1 and riverbed conductance are not presented because order-of-magnitude changes in these parameters had no effect on simulated hydraulic heads. A multiplication factor greater than 1 for generalhead-boundary conductances had no effect on head residuals (fig. 11). Model parameters, in order of decreasing sensitivity to changes in ground-water discharge to the Scioto and Blanchard Rivers, were (1) transmissivity of layer 2, (2) vertical leakance between layers 1 and 2, (3) hydraulic conductivity of layer 1, (4) riverbed hydraulic conductivity, (5) general-head-boundary conductance, and (6) areal recharge. Flow responses are reported as percentage change in flow (figs. 12-14). Selected hydraulic heads and ground-water discharges from the sensitivity analysis are shown in table 3 .

\section{Patterns of Ground-Water Flow}

Simulated hydraulic heads and cell-to-cell flows from the calibrated model were used as input to a particle-tracking program (Pollock, 1989) to compute ground-water pathlines and traveltimes along the simulated regional flow path. The resulting patterns of flow and areas of significant recharge and discharge are shown in figure 15 . The direction of ground-water flow is from south (A) to north $\left(A^{\prime}\right)$ for all pathlines.

The simulation substantiates the concept that the regional flow path is within a continuous ground-water basin. Some of the water entering the ground-water system at the regional topographic high (column 1) flows near the bottom of the carbonate-rock aquifer and discharges into Sandusky Bay.

The general pattern of flow appears to be largely controlled by the configuration of the water table. The distance and depth that ground water travels and the traveltime from point of recharge to point of discharge appear to be controlled largely by where ground water enters the flow system. An analysis of cell-to-cell flows from the calibrated model indicates that 84 percent of the water entering the ground-water system flows less than 


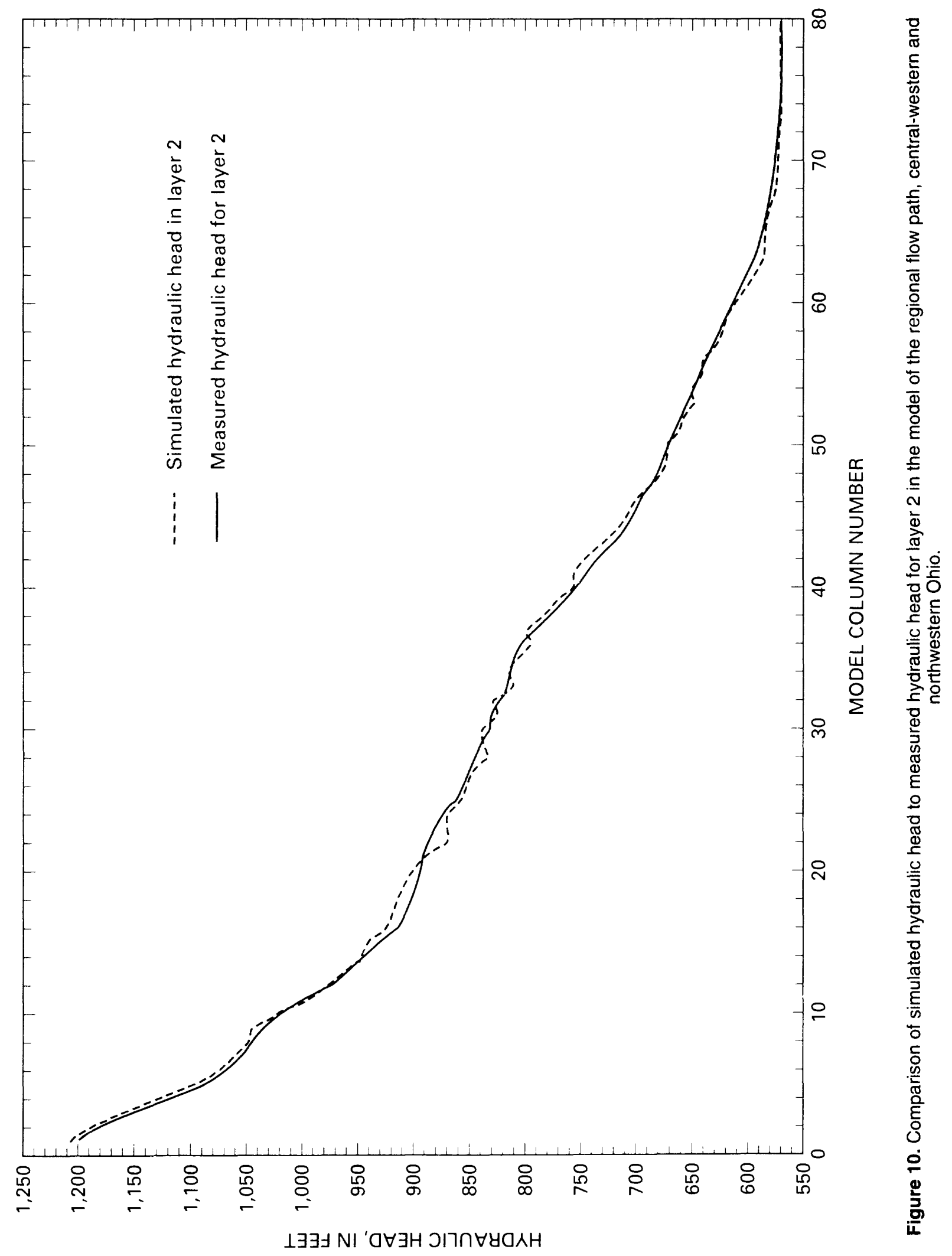



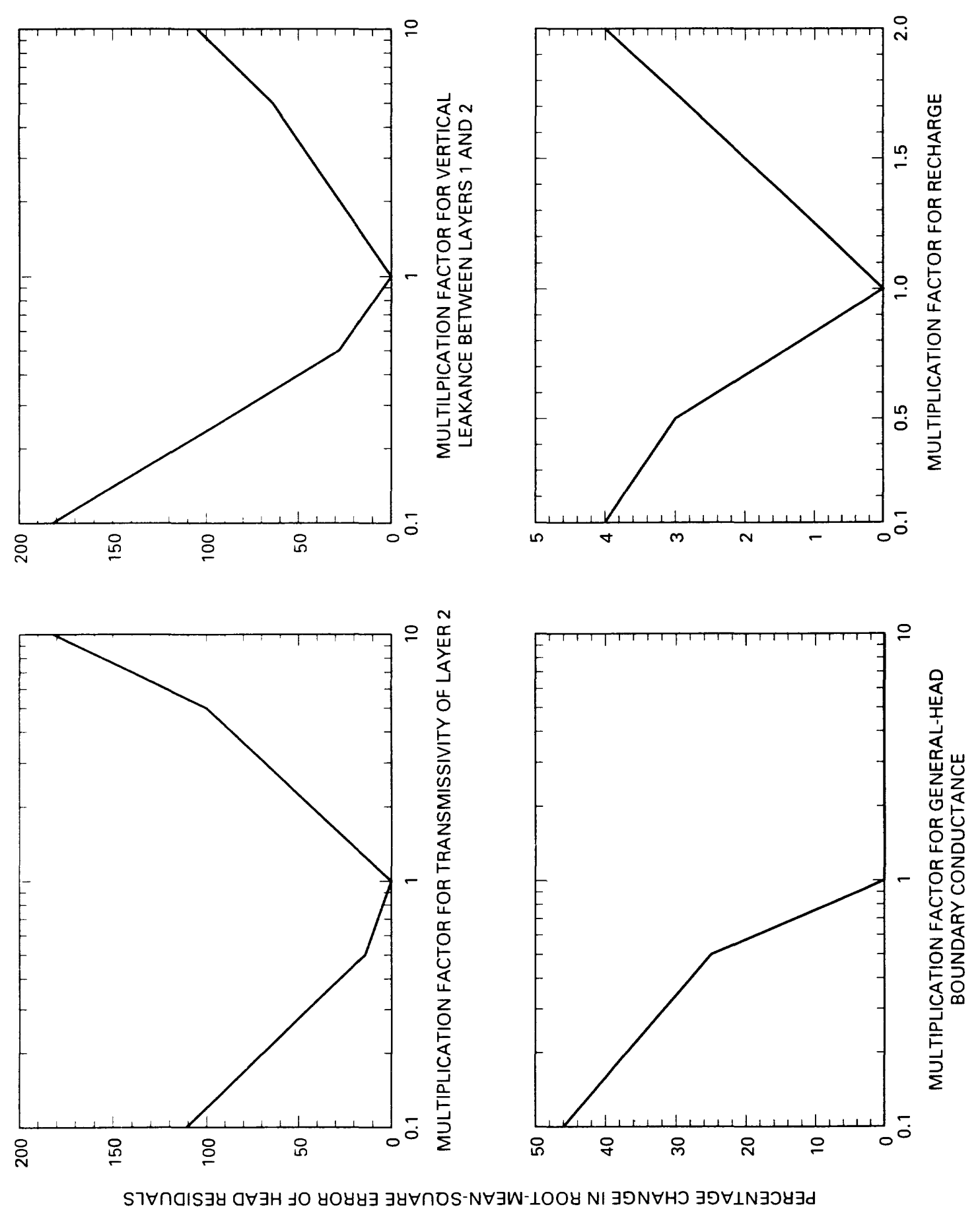

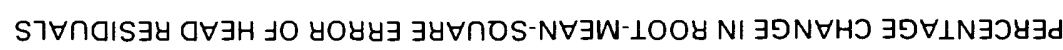



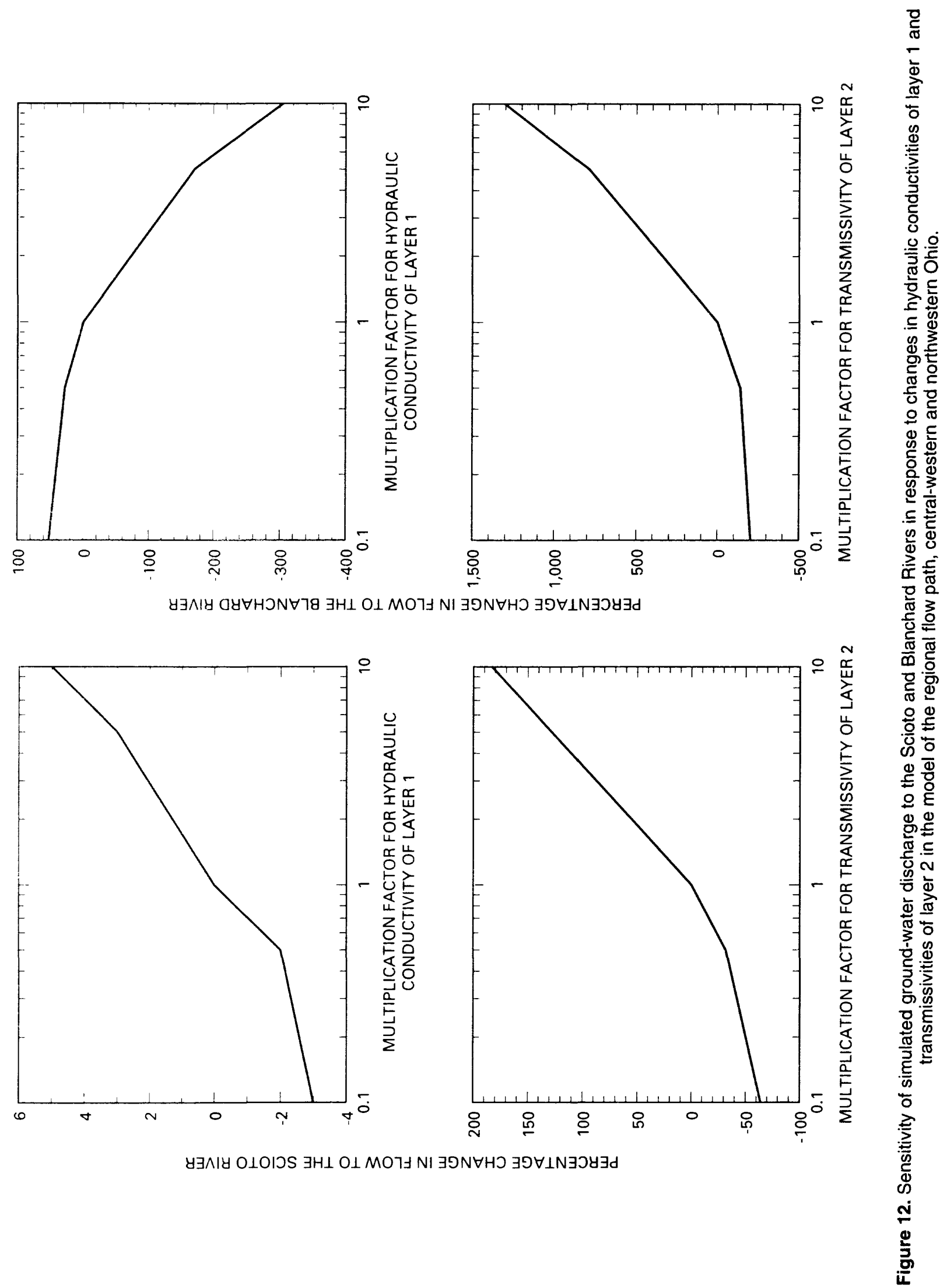

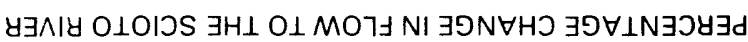



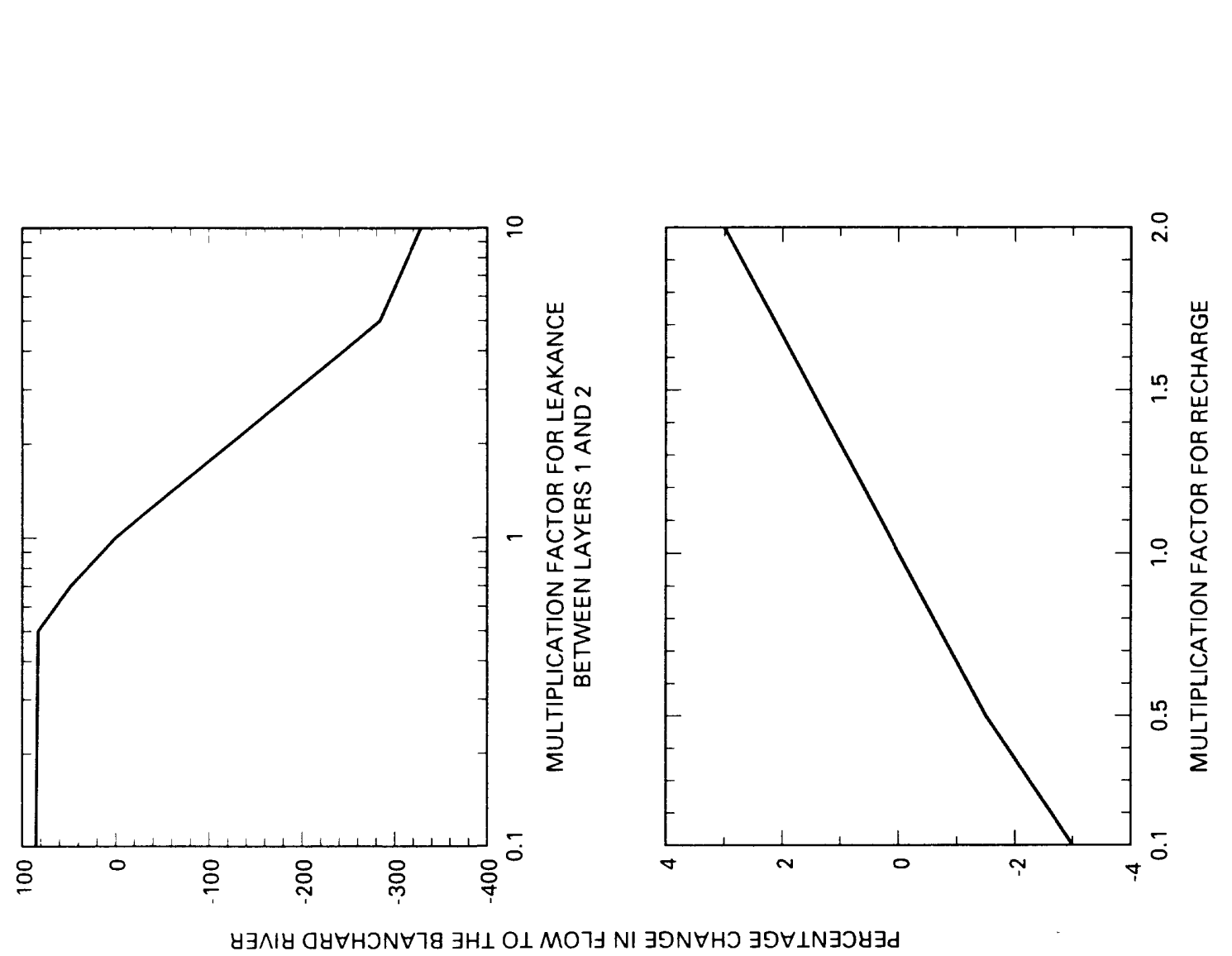

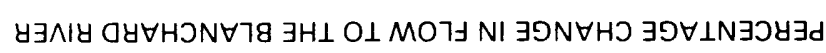
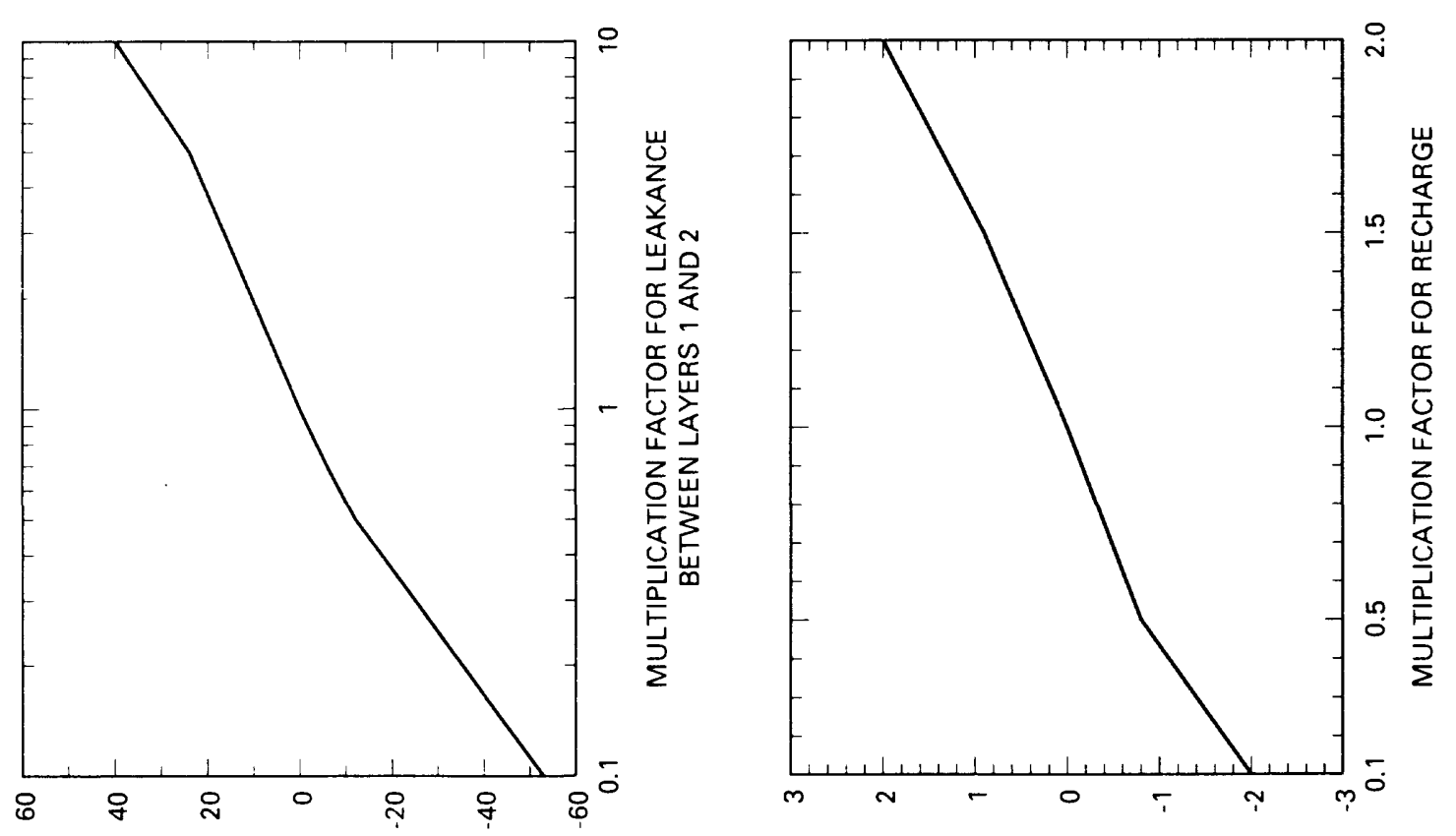

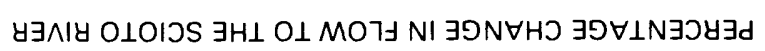



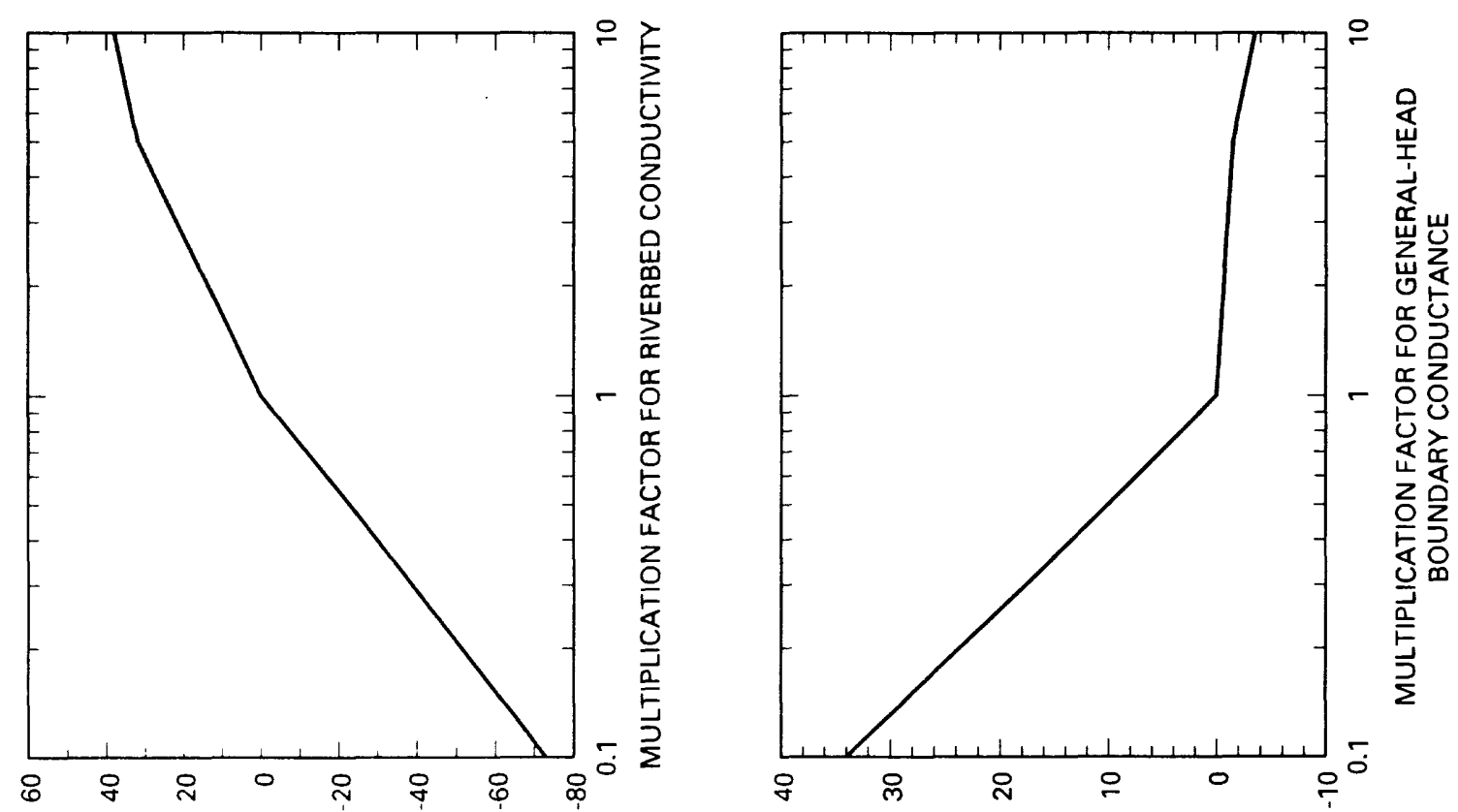

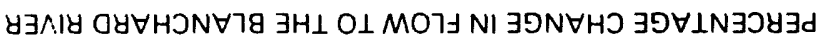
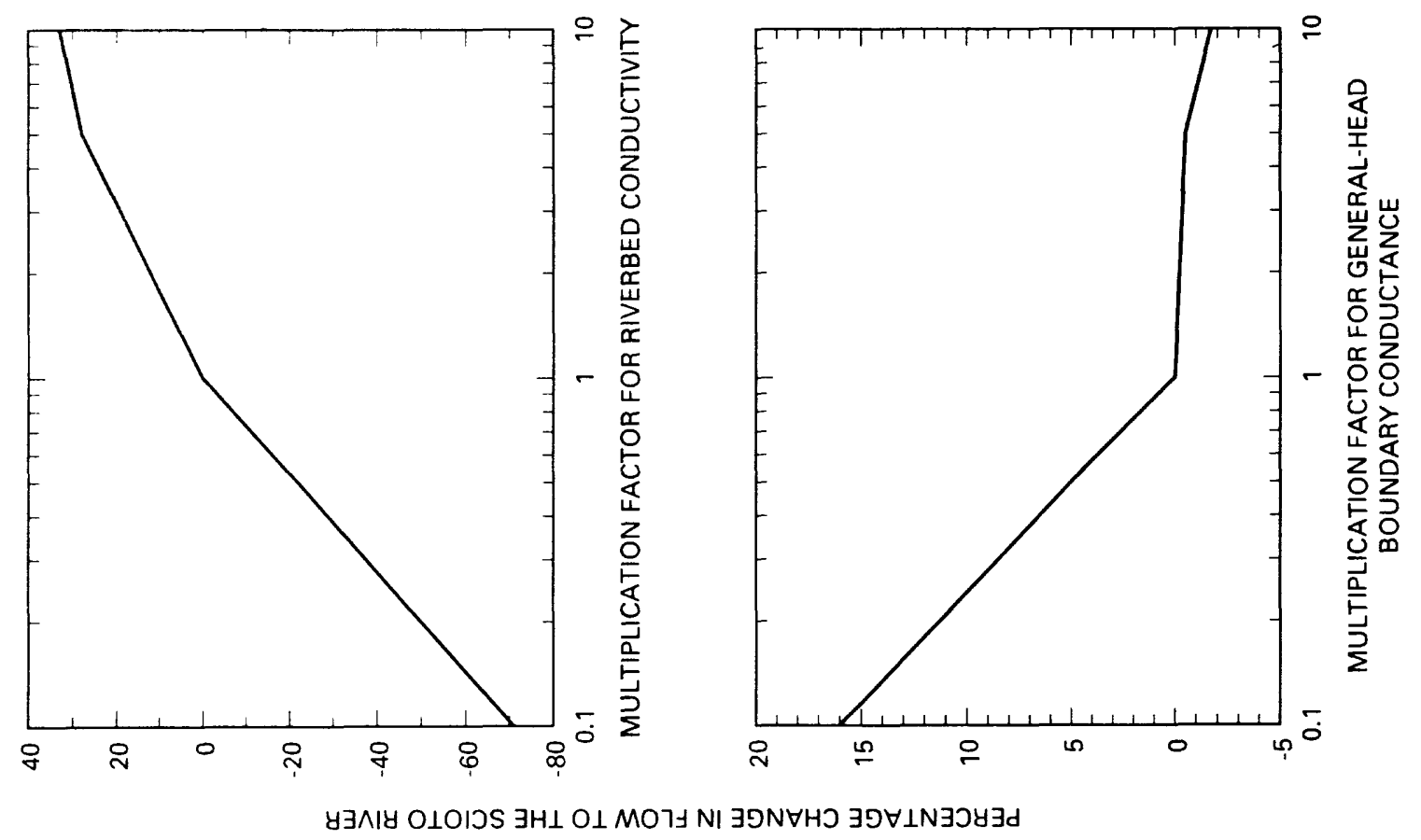
Table 3. Selected hydraulic heads and ground-water discharges from sensitivity analysis of hydrologic parameters used in calibrating the model of the regional ground-water flow path, Ohio

$$
\left[\mathrm{ft}^{3} / \mathrm{d}\right. \text {, cubic feet per day; values from the calibrated model are in bold type] }
$$

\begin{tabular}{|c|c|c|c|c|c|c|c|c|c|c|c|}
\hline \multirow{2}{*}{$\begin{array}{c}\text { Multi- } \\
\text { plier of } \\
\text { hydro- } \\
\text { logic } \\
\text { para- } \\
\text { meter } \\
\text { array }\end{array}$} & \multirow{2}{*}{$\begin{array}{l}\text { Dis- } \\
\text { charge } \\
\text { to the } \\
\text { Scioto } \\
\text { River } \\
\left(\mathrm{ft}^{3} / \mathrm{d}\right)\end{array}$} & \multirow{2}{*}{$\begin{array}{l}\text { Dis- } \\
\text { charge } \\
\text { to the } \\
\text { Blan- } \\
\text { chard } \\
\text { River } \\
\left(\mathrm{ft}^{3} / \mathrm{d}\right)\end{array}$} & \multicolumn{9}{|c|}{ Altitude of hydraulic head in layer 2 from model output (feet) } \\
\hline & & & Cell 1 & Cell 10 & Cell 20 & Cell 30 & Cell 40 & Cell 50 & Cell 60 & Cell 70 & Cell 80 \\
\hline \multicolumn{12}{|c|}{ Transmissivity of layer 2} \\
\hline 0.1 & 0.3648 & -0.5558 & 1,220 & 1,034 & 896 & 827 & 752 & 670 & 616 & 576 & 571 \\
\hline .5 & .6800 & -.2137 & 1,163 & 1,025 & 896 & 830 & 753 & 670 & 615 & 576 & 571 \\
\hline 1.0 & 1.0042 & 0.5429 & 1,138 & 1,021 & 895 & 832 & 754 & 670 & 615 & 577 & 571 \\
\hline 5.0 & 2.2856 & 4.8178 & 1,090 & 1,014 & 897 & 833 & 754 & 670 & 617 & 582 & 576 \\
\hline 10.0 & 2.8392 & 7.6232 & 1,069 & 1,010 & 900 & 833 & 754 & 670 & 619 & 588 & 582 \\
\hline \multicolumn{12}{|c|}{ Recharge } \\
\hline 0.1 & 0.9884 & 0.5281 & 1,138 & 1,021 & 895 & 831 & 754 & 670 & 615 & 577 & 571 \\
\hline .5 & .9954 & .5347 & 1,138 & 1,021 & 895 & 831 & 754 & 670 & 615 & 577 & 571 \\
\hline 1.0 & 1.0042 & .5429 & 1,138 & 1,021 & 896 & 832 & 754 & 670 & 615 & 577 & 571 \\
\hline 1.5 & 1.0130 & .5512 & 1,138 & 1,021 & 896 & 832 & 754 & 670 & 615 & 577 & 571 \\
\hline 2.0 & 1.0217 & .5595 & 1,138 & 1,021 & 895 & 833 & 754 & 670 & 615 & 577 & 571 \\
\hline \multicolumn{12}{|c|}{ Hydraulic conductivity of layer 1} \\
\hline 0.1 & 0.9835 & 0.8249 & 1,139 & 1,021 & 895 & 832 & 754 & 670 & 615 & 577 & 571 \\
\hline .5 & .9943 & .6947 & 1,139 & 1,021 & 895 & 832 & 754 & 670 & 615 & 577 & 571 \\
\hline 1.0 & 1.0042 & .5429 & 1,138 & 1,021 & 895 & 832 & 754 & 670 & 615 & 577 & 571 \\
\hline 5.0 & 1.0230 & -.3836 & 1,138 & 1,021 & 895 & 832 & 754 & 670 & 615 & 577 & 571 \\
\hline 10.0 & 1.0361 & -1.1104 & 1,138 & 1,021 & 895 & 831 & 754 & 670 & 615 & 577 & 571 \\
\hline \multicolumn{12}{|c|}{ Vertical hydraulic conductivity of riverbed/lakebed } \\
\hline 0.1 & 0.2874 & 0.1465 & 1,138 & 1,021 & 895 & 831 & 754 & 670 & 615 & 577 & 570 \\
\hline .5 & .7864 & .4172 & 1,138 & 1,021 & 895 & 831 & 754 & 670 & 615 & 577 & 571 \\
\hline 1.0 & 1.0042 & .5429 & 1,138 & 1,021 & 895 & 832 & 754 & 670 & 615 & 577 & 571 \\
\hline 5.0 & 1.2897 & .7165 & 1,138 & 1,021 & 895 & 831 & 754 & 670 & 615 & 577 & 571 \\
\hline 10.0 & 1.3376 & .7469 & 1,138 & 1,021 & 895 & 831 & 754 & 670 & 615 & 577 & 571 \\
\hline \multicolumn{12}{|c|}{ Leakance between layers 1 and 2} \\
\hline 0.1 & 0.4801 & 1.0266 & 1,069 & 1,010 & 898 & 833 & 755 & 671 & 619 & 588 & 582 \\
\hline .5 & .8789 & .9977 & 1,116 & 1,018 & 895 & 833 & 754 & 670 & 615 & 578 & 572 \\
\hline 1.0 & 1.0042 & .5429 & 1,138 & 1,021 & 895 & 832 & 754 & 670 & 615 & 577 & 571 \\
\hline 5.0 & 1.2453 & -1.0016 & 1,195 & 1,031 & 896 & 828 & 753 & 670 & 615 & 576 & 570 \\
\hline 10.0 & 1.4030 & -1.2400 & 1,215 & 1,034 & 896 & 827 & 753 & 670 & 615 & 576 & 570 \\
\hline \multicolumn{12}{|c|}{ General-head boundary conductance } \\
\hline 0.1 & 1.1631 & 0.7249 & 1,139 & 1,022 & 896 & 838 & 755 & 671 & 615 & 577 & 571 \\
\hline .5 & 1.0072 & .5704 & 1,139 & 1,021 & 895 & 831 & 754 & 670 & 615 & 577 & 571 \\
\hline 1.0 & 1.0042 & .5429 & 1,138 & 1,021 & 895 & 832 & 754 & 670 & 615 & 577 & 571 \\
\hline 5.0 & .9853 & .5222 & 1,138 & 1,021 & 895 & 831 & 754 & 670 & 615 & 577 & 571 \\
\hline 10.0 & .9871 & .5239 & 1,138 & 1,021 & 895 & 831 & 754 & 670 & 615 & 577 & 571 \\
\hline
\end{tabular}




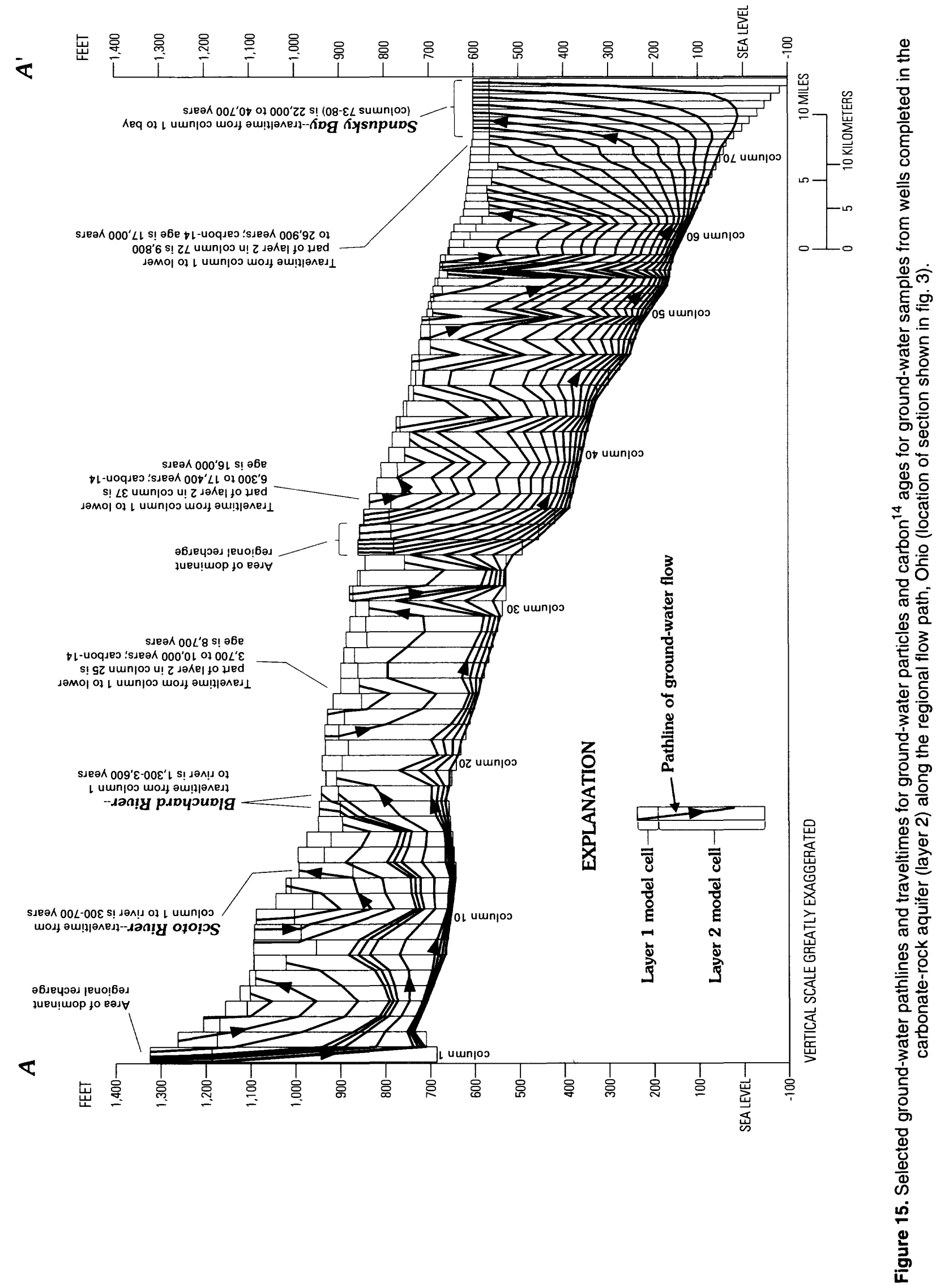


$5 \mathrm{mi}$ from point of recharge to point of discharge and no deeper than the surficial aquifers. This ground water can be considered to be confined to the local-flow subsystem. Ground water entering the carbonate bedrock generally flows longer distances than ground water in the glacial deposits and may enter the intermediate- or regional-flow subsystem. Ground water in the regional-flow subsystem enters the flow system near two major topographic highs or divides (columns 1, 34, and 35 ) and flows deeper and farther than ground water that enters the system elsewhere along the regional flow path. Model columns 34 and 35 represent an area of very thin glacial deposits covering limestone ridges.

The model is less discretized vertically than horizontally, and perturbations in pathlines (such as near the bottom of the carbonate-rock aquifer near columns 20 and 30) are partially a result of the chosen degree of vertical discretization of the model. These perturbations are exaggerated because the particle-tracking program calculates the vertical component of velocity as varying linearly from the top to the bottom of each cell, whereas the horizontal component of velocity is calculated as a constant within each cell (D.W. Pollock, U.S. Geological Survey, oral commun., 1993).

\section{Ground-Water Traveltimes}

The particle-tracking program computes traveltimes for ground-water particles. Traveltimes for ground water are greatly affected by aquifer porosity. The porosity of the carbonate bedrock in northwestern Ohio, calculated from resistivity and neutron logs, ranges from 8 to 22 percent (MacCary, 1971). Within this range of porosity, traveltimes computed for ground water traveling along the longest pathlines from column 1 to the Scioto River, the Blanchard River, and Sandusky Bay ranged from 300 to 700 years, 1,300 to 3,600 years, and 22,000 to 40,700 years, respectively (fig. 15). Traveltimes for ground water from the regional topographic high to near the bottom of model columns 25,37 , and 72 ranged from 3,700 to 10,000 years, 6,300 to 17,400 years, and 9,800 to 26,900 years, respectively; carbon $^{14}$ ages for ground-water samples taken from wells which penetrate a significant portion of the carbonate-rock aquifer near these columns along the regional flow path were 8,700 years, 16,000 years, and 17,000 years, respectively (L.L. Lesney, U.S. Geological Survey, written commun., 1993) (fig. 15).

\section{Limitations}

All ground-water models are only approximations of actual systems. The chosen degree of model discretization affects the averaging of input parameters, which, in turn, affects the accuracy and utility of results. In addition, assumptions may be incorrect and (or) there may be unknown hydrologic features that are not represented in the model, which, if known, would affect model results.

Recharge rates derived from hydrograph separation analyses for surface-water basins are gross averages. Actual site-specific recharge rates are affected by surficial geology, which can vary considerably within a given surface-water basin and affect these rates over relatively short distances. Hence, recharge rates derived from regional analyses may be inappropriate for sitespecific studies.

Estimates of ground-water discharge to rivers derived from hydrograph-separation analyses are gross averages for surface-water basins. Groundwater discharge per unit length of a gaining river normally increases downstream as the river becomes deeper and (or) wider. Ground-water discharge to the two rivers used in this analysis, as calculated from hydrograph separation, may be less than the average discharge per unit length of river used for calibration because both rivers cross the trend of the regional flow path relatively close to their headwaters (fig. 2). If actual ground-water discharge is less than the average discharge per unit length of river where the rivers cross the trend of the regional flow path, then simulated riverbed conductivities are too large.

The no-flow boundary in Sandusky Bay was arbitrarily placed, and some ground water may discharge farther into Lake Erie than was simulated in the model. The model-calculated vertical hydraulic conductivities of the lakebed would have been smaller if the no-flow boundary had been placed farther from shore. 


\section{SUMMARY AND CONCLUSIONS}

An analysis of ground-water flow along a selected regional ground-water flow path in central-western and northwestern Ohio was done as part of the Midwestern Basins and Arches Regional Aquifer-System Analysis project. The Midwestern Basins and Arches aquifer system is composed of carbonate bedrock of Silurian and Devonian age and overlying glacial deposits of Quaternary age. The selected regional groundwater flow path begins at a regional topographic high in Logan County, Ohio, and ends in Sandusky Bay (Lake Erie), a regional topographic low.

The general pattern of ground-water flow seems to be largely controlled by the configuration of the water table, which follows land-surface topography along the selected regional groundwater flow path. The distance and depth that ground water travels and the traveltime from point of recharge to point of discharge are controlled largely by where ground water enters the flow system. An analysis of cell-to-cell flows from the calibrated ground-water flow model indicates that 84 percent of the water entering the ground-water system flows less than $5 \mathrm{mi}$ from point of recharge to point of discharge and no deeper than the surficial aquifers. This ground water can be considered to be confined to the local-flow subsystem. Ground water in the local-flow subsystem is most affected by seasonal variations in recharge. Ground water entering the carbonate bedrock generally flows longer distances than ground water in the glacial deposits and may enter the intermediate- or regional-flow subsystem. Ground water in the regional-flow subsystem enters the flow system near two major topographic highs or divides and flows deeper and longer distances than ground water that enters the system elsewhere along the selected regional ground-water flow path. Ground-water discharge to major surface-water bodies during extended and severe periods of drought is sustained by ground water from the deeper intermediate- and regional-flow subsystems.

A particle-tracking simulation substantiates the concept that the selected regional ground-water flow path is within a continuous ground-water basin. Some of the water that recharges the ground-water system at the regional topographic high enters the regional-flow subsystem, flows near the bottom of the carbonate-rock aquifer, and discharges to Sandusky Bay.

Model-simulation results indicate that as simulated vertical hydraulic conductivity of the lakebed in Sandusky Bay is decreased, simulated groundwater discharge results farther from shore. Modeling results also indicate that variation of vertical hydraulic conductivity of the lakebed has no appreciable effect on either the quantity of ground water that discharges into Sandusky Bay or the hydraulic head at any point within the aquifer system.

Given a range of carbonate-bedrock porosities from 8 to 22 percent, traveltimes that were computed for ground water traveling along the longest pathlines to the Scioto River, the Blanchard River, and Sandusky Bay ranged from 300 to 700 years, 1,300 to 3,600 years, and 22,000 to 40,700 years, respectively. Traveltimes for ground water from the regional topographic high to near the bottom of model columns 25,37 , and 72 ranged from 3,700 to 10,000 years, 6,300 to 17,400 years, and 9,800 to 26,900 years, respectively, compared to carbon ${ }^{14}$ ages for ground-water samples collected from wells near these columns along the selected regional ground-water flow path of 8,700 years, 16,000 years, and 17,000 years, respectively.

\section{REFERENCES CITED}

Anderson, R.H., 1987, Geophysical measurement and computer modeling of ground-water flux through lake sediments-Lake St. Clair, Michigan/ Ontario: University of Wisconsin-Milwaukee, Department of Geosciences, unpublished M.S. thesis, $140 \mathrm{p}$.

Arihood, L.D., 1994, Hydrogeology and paths of flow in the carbonate bedrock aquifer, northwestern Indiana: Water Resources Bulletin, v. 30, no. 2, $14 \mathrm{p}$.

Beary, E.A., 1993, Ground-water withdrawal in 1990Midwestern Basins and Arches Regional Aquifer Systems study area: U.S. Geological Survey Open-File Report 93-119, 2 p.

Breen, K.J., and Dumouchelle, D.H., 1991, Geohydrology and quality of water in aquifers in Lucas, Sandusky, and Wood Counties, northwestern Ohio: U.S. Geological Survey Water-Resources Investigations Report 91-4024, $234 \mathrm{p}$. 
Bugliosi, E.F., 1990, Plan of study for the Ohio-Indiana carbonate-bedrock and glacial-aquifer system: U.S. Geological Survey Open-File Report 90-151,26 p.

Buxton, H.T., and Modica, Edward, 1992, Patterns and rates of ground-water flow on Long Island, New York: Ground Water, v. 30, p. 857-866.

Casey, G.D., 1992, Hydrogeology of the basal confining unit of the carbonate aquifer system in the Midwestern Basins and Arches Region of Indiana, Ohio, Michigan, and Illinois: U.S. Geological Survey Open-File Report 92-489, 2 pls., scale $1: 1,000,000$.

Fenneman, N.M., 1938, Physiography of eastern United States: New York, McGraw-Hill Book Co., 689 p.

Forsyth, J.L., 1968, A study of the physical features of the Toledo regional area: Toledo Regional Area Plan for Action Report 8.2, $111 \mathrm{p}$.

Freeze, R.A., and Cherry, J.A., 1979, Groundwater: Englewood Cliffs, N.J., Prentice-Hall, 604 p.

Freeze, R.A., and Witherspoon, P.A., 1967, Theoretical analysis of regional groundwater flow, 2. Effect of water-table configuration and subsurface permeability variation: Water Resources Research, v. 3, no. 2, p. 623-634.

Goldthwait, R.P., White, G.W., and Forsyth, J.L., 1979, Glacial map of Ohio: Ohio Department of Natural Resources, Division of Geological Survey Miscellaneous Geological Investigations Map I-316, scale 1:500,000.

Hull, D.N., 1990, Generalized column of bedrock units in Ohio: Ohio Department of Natural Resources, Division of Geological Survey, 1 p.

Janssens, Adriaan, 1977, Silurian rocks in the subsurface of northwestern Ohio: Ohio Department of Natural Resources, Division of Geological Survey Report of Investigations 100, $96 \mathrm{p}$.

Joseph, R.L. and Eberts, S.M., 1994, Selected data on characteristics of glacial deposit and carbonaterock aquifers, Midwestern Basins and Arches Region: U.S. Geological Survey Open-File Report 93-627, $43 \mathrm{p}$.

Larsen, G.E., 1991, Development of Silurian and Devonian lithostratigraphic nomenclature, centralwestern and northwestern Ohio: Ohio Department of Natural Resources, Geological Survey Open-File Report 91-1, 1 pl.

MacCary, L.M., 1971, Resistivity and neutron logging in Silurian dolomite of northwest Ohio: U.S. Geological Survey Professional Paper 750-D, p. D190-D197.

McDonald, M.G., and Harbaugh, A.W., 1988, A modular finite-difference ground-water flow model: U.S. Geological Survey Techniques of
Water-Resources Investigations, book 6, chap. A1, $586 \mathrm{p}$.

Norris, S.E., 1962, Permeability of glacial till: U.S. Geological Survey Professional Paper 450-E, p. E150-E151.

Ohio Department of Natural Resources, 1970, Ground water for planning in northwest Ohio-A study of carbonate rock aquifers: Ohio Water Plan Inventory Report 22, $63 \mathrm{p}$.

Pavey, R.R., and Goldthwait, R.P., 1993, Quaternary geology of Ohio, Marion quadrangle: Ohio Department of Natural Resources, Division of Geological Survey Open-File Map 295, scale 1:250,000.

Pettyjohn, W.A., and Henning, R.J., 1979, Preliminary estimate of ground-water recharge rates, related streamflow and water quality in Ohio: The Ohio State University, Department of Geology and Mineralogy Project Completion Report 552, 323 p.

Pollock, D.W., 1989, Documentation of computer programs to compute and display pathlines using results from the U.S. Geological Survey modular three-dimensional finite-difference ground-water flow model: U.S. Geological Survey Open-File Report 89-381, 188 p.

Shaver, R.H., 1991, A history of study of Silurian reefs in the Michigan Basin environs: Geological Society of America Special Paper 256, p. 101-138.

Strobel, M.L., 1993, Hydraulic properties of selected glacial and lacustrine deposits in Ohio: U.S. Geological Survey Water-Resources Investigations Report 92-4135, 59 p.

Sun, R.J., 1984, Regional Aquifer-System Analysis Program of the U.S. Geological SurveySummary of projects, 1978-84: U.S. Geological Survey Circular 1002, $264 \mathrm{p}$.

Textoris, D.A., and Carozzi, A.V., 1966, Petrography of Cayugan (Silurian) stromatolite mound and associated facies, Ohio: American Association of Petroleum Geologists Bulletin, v. 50, p. 1375-1388.

Toth, Jozsef, 1963, A theoretical analysis of ground-water flow in small drainage basins: Journal of Geophysical Research, v. 68, no. 16, p. $4795-4812$.

Wang, H.F., and Anderson, M.P., 1982, Introduction to groundwater modeling: New York, W.H. Freeman and Co., $237 \mathrm{p}$.

Williams, T.A., and Williamson, A.K., 1989, Estimating water-table altitude for regional ground-water flow modeling, U.S. Gulf Coast: Ground Water, v. 27, no. 3, p. 333-345. 